\title{
Hepatotoxic Botanicals - An Evidence-based Systematic Review
}

\author{
Reem J. Abdualmjid and Consolato Sergi \\ Department of Laboratory Medicine and Pathology, University of Alberta, Edmonton, Alberta, Canada
}

Received April 22, 2013; Accepted, April 26, 2013, Published, April 30, 2013.

\begin{abstract}
Purpose. Herbal medicines have been increasingly used worldwide. However, the potential harms of these herbs have been noticed most recently following hepatotoxicity with ingestion of herbal remedies. The aim of this review is to evaluate the evidence of hepatotoxic effects linked to use of herbal preparations. Method. Electronic search was performed by searching several databases: PubMed, HerbMed, Google Scholar, Scopus, Cochrane Database of Systematic Reviews and Cochrane Library using both Latin and common names of several herbs. Language was restricted to English and articles were selected for relevance reporting incidence of hepatotoxicity associated with use of herbal products in human. Results. From a total of 565 relevant reviews and articles, 254 met our inclusion criteria and were analyzed. Serious hepatotoxic events associated with various herbal products alone or in combination with other drugs have been reported. Linking to herbal constituents the spectrum of liver toxicity includes elevated liver enzymes, acute or chronic hepatitis, cholestasis, hepatic necrosis, fibrosis, and cirrhosis, as well as acute liver failure and hepatic veno-occlusive disease. Conclusion. The hepatotoxicity of herbs was extensively acknowledged. As the use of natural medicine increases, the risk of liver toxicity and drug interaction increase as well. Accordingly, herbal remedies have been known as hepatotoxins causing several liver damages. Further scientific studies with high and good quality are needed to identify toxic compounds and understand the exact mechanism of hepatotoxicity-induced by herbs. The adverse effects of herbal products must be fully reported as well as extensive education of healthcare providers must be provided in order to reduce danger of alternative medicines.
\end{abstract}

This article is open to POST-PUBLICATION REVIEW. Registered readers (see "For Readers") may comment by clicking on ABSTRACT on the issue's contents page.

\section{INTRODUCTION}

The use of alternative medicine or phytotherapy can be traced back in old manuscripts coming from ancient China, India, Iran, Korea and Egypt. During the past several decades, the use of herbal medicines has been expanded and gained more attention due to their therapeutic potentials $(1,2)$. Certain factors contributed to the increasing use of herbal medicine including effectiveness, availability, affordability, and, apparently, safety (3). It has been estimated that over 500 herbal products are distributed as harmless healthy products worldwide (4). As compared to conventional therapy, natural therapy is believed to be free of side effects (5).

Liver is the largest and most vital organ in human body and able to detoxify several chemical compounds (6). The occurrence of liver toxicity cases linked to herbal medicine raises some concerns regarding herbal safety $(7,8,9)$. According to two reviews, several case reports reported severe hepatic damage associated with botanicals alone or in combination with other medications $(7,10)$. The toxicity of herbs is probably due to several factors such as plant component that has been used, storage conditions of plant, mislabeling or misidentification of plant, and contaminations (11). Recently, different hepatic reactions involving botanicals have been documented (12). The spectrum of liver toxicity includes elevated liver enzymes, acute or chronic hepatitis, cholestasis, hepatic necrosis or fibrosis, cirrhosis, liver failure, and hepatic veno-occlusive disease $(12,13)$. Some of botanicals that raised severe health concerns are Black cohosh (14), Chaparral (15), Saw palmetto (16), Comfrey (8), Germander (17) Kava (18) and many others as described in this review.

The purpose of this paper is to review already published cases and spontaneous reports of the hepatotoxicity of each botanical and systemically assess the evidence of hepatotoxic events associated with these herbs as well as providing botanical names, synonyms, active constituents,

Corresponding Author: Consolato M. Sergi, MSc, MD, PhD; Department of Lab. Medicine and Pathology; University of Alberta Hospital; Edmonton, Alberta; Canada; Email: sergi@ualberta.ca 
potential herb-herb interaction or herb-drug interaction and possible mechanisms of toxicity.

\section{METHODS}

We reviewed scientific articles that were obtained from PubMed, HerbMed, Scopus, Google Scholar, the Cochrane Database of Systematic Reviews and Cochrane Library databases between 1900 and 2013. We used the following search terms: herbal hepatotoxicity, hepatotoxic plants, liver toxicity, botanicals hepatotoxicity, toxic hepatitis, herbal remedies, alternative medicine, complementary therapy as well as the common and Latin name of botanicals. The search was restricted to English language articles and Human studies only.

\section{RESULTS}

The search generated 565 relevant papers, of which 310 were excluded as shown in Figure 1. A list of herbs with hepatotoxic effects is shown in Table 1. Our search identified cases that provided evidence of hepatotoxicity of certain herbs. In addition, we indicated whether medicinal botanicals were alone or combined with other drugs implicated in several hepatotoxic incidents. Moreover, several possible mechanisms of herbs causing hepatotoxicity appear to be involved and are summarized in Table 1. In some case reports we did not find enough scientific documentation and limited information of several herbs was provided. However, we combined the knowledge derived from phytotherapy and liver metabolism to provide a unique comprehensive guide for pharmacologists and pharmaceutical scientists.

\section{Black cohosh (Actea racemosa):}

Actea racemosa is a perennial, woodland herb with a thick root system (rhizome) that belongs to Ranunculaceae family and is native to North America (Figure 2A) (19). Cimicifuga racemosa is one synonym of this plant and other names include black coach, black snakeroot, rattleroot, bugwort, macrotys and bugbane (20). The root of black cohosh has been used by Native American Indians for treating several conditions like colds, coughs, fatigue, and constipation (21). In particular, cimicifuga rhizomes have been used as treatment for menopause-related symptoms, rheumatism, dysmenorrhea, and premenstrual discomfort $(21,22)$.
Total number of electronic search of hepatotoxic botanicals $(n=565)$

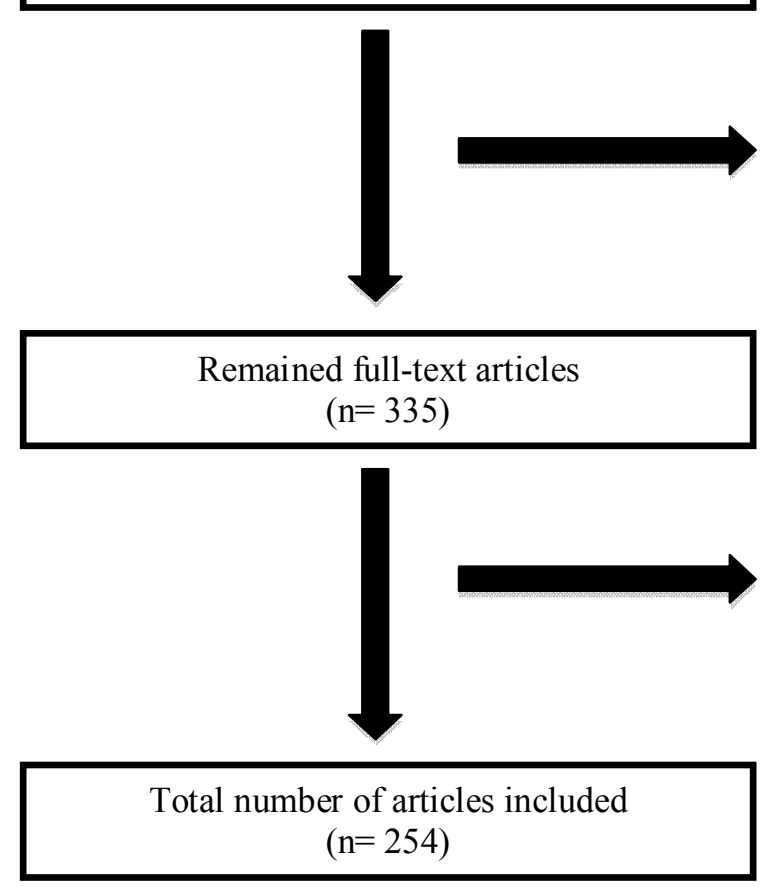

Studies excluded after language restriction $(n=230)$

Figure 1. Flow chart. 
The main active constituent of black cohosh rhizome is terpene glycosides like actein, cimicifugoside and 27-deoxyactein as well as some other active constituents like alkaloids, flavonoids and tannins (23). Several studies have been conducted to determine the safety of black cohosh. Some of these studies suggested that Cimicifuga extract causes severe acute hepatitis and liver failure and autoimmune mechanism has been proposed $(14,24,25)$. In fact, Cohen et al. (25) reported the first case of autoimmune hepatitis associated with the use of black cohosh in a 57-year-old woman without history of liver disease. She started to use black cohosh to treat "hot flashes", but she developed autoimmune hepatitis. Another case report mentions a relationship between the use of cimicifuga and acute hepatitis (14). A 47-year-old woman with no history of liver disease took black cohosh for one week with no other medication to treat menopause symptoms. Severe hepatitis and jaundice developed following ingestion leading to liver transplant. In the report by Levitsky et al. (24), a 50-year-old woman had black cohosh root daily as a medication for menopause symptoms. The patient was admitted to the hospital for liver transplantation due to development of acute fulminant hepatitis with diffuse cell necrosis and cholestasis.

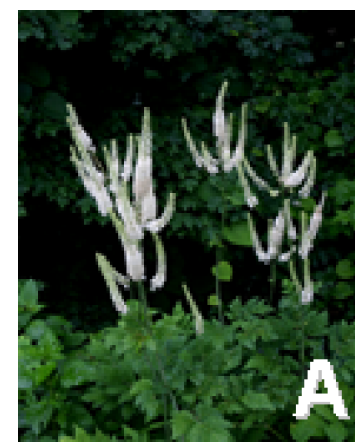

Figure 2: Hepatotoxic Plant (A) Black Cohosh (Actaea Racemosa) (26)

\section{Chaparral (Larrea tridentata):}

Chaparral is an evergreen desert shrub, which is made of leaves of greasewood or creosote bush (Figure 2B). It is native to the southwestern United States and Mexico (15,27). Larrea tridentate is the botanical name of chaparral and other synonyms include L. glutinosa Engelm and L. divaricata Cav. (28). Ancient Native Americans have used chaparral as tea to treat rheumatic pain and bronchitis. It also has been used in different forms like capsules and tablets for the treatment of other conditions such as diarrhea, cold, rheumatism, urinary tract infection, and chronic skin diseases $(29,30)$. Among herbs, chaparral is probably the best known antibiotic treatment derived from plants (31). Nordihydroguaiaretic acid (NDGA) has been proposed as the active constituent of chaparral. NDGA is an antioxidant and an inhibitor of two biochemical pathways involving cyclo-oxygenase and lipoxygenase $(28,31)$. Some of reported side effects of chaparral include: vomiting, diarrhea, rash, fever, and abdominal cramp (28). Hepatotoxicity is the major problem linked to chaparral ingestion (32). A review done by Sheikh et al. (15) reviewed 18 cases of illnesses following chaparral ingestion. The age range of 13 patients was 25-60 and jaundice was the main sign of liver disease. Liver injury also included cholestatic hepatitis, fulminant liver failure, and rash progression to cirrhosis. In a 22 years old woman, the hepatotoxicity developed during the breastfeeding period following delivery of a healthy newborn and ingestion of chaparral to increase milk secretion (31). Her liver biopsy and lab findings confirmed the diagnosis of acute druginduced hepatitis as well as hepatic fibrosis. Another report of a male individual of 27 years of age developed hepatitis after 12 month of taking chaparral to prevent illness (28).

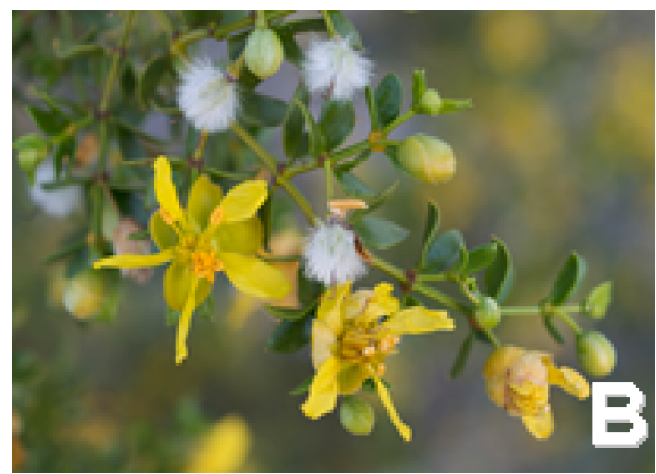

Figure 2: Hepatotoxic Plant (B) Chaparral (Larrea tridentata) (33)

\section{Saw palmetto (Serenoa repens):}

Serenoa repens (S. repens), commonly known as saw palmetto or scrub palmetto, is the most common herb used for treatment of symptoms of benign prostatic hyperplasia $(\mathrm{BPH})$ and urinary tract infection (UTI) (34). It is a dried ripe fruit of American dwarf palm tree that is native to West Indies and South-eastern America. It is also known as Sabal serrulata and Serenoa serrulata (botanical names) (Figure 2C) $(35,36)$. The preparation of saw palmetto is called prostata and it is composed of fatty acids and phytosterols (37). The most active ingredients of saw palmetto 
are steroidal and sitosterol compounds (35). Furthermore, saw palmetto has estrogenic and antiandrogenic properties (38). Obviously, both estrogen and antiandrogen can be hepatotoxic. In fact, high levels of estrogen are associated with cholestatic effects and antiandrogen effects include fulminant hepatitis $(39,40)$. Few studies and case reports have reported some toxicity of $S$. repens. A case report reported the association between prostata and protracted cholestatic hepatitis in 65-year-old man taking this herbal preparation to treat nocturia and hesitancy (39). Additionally, Lapi et al. (41) reported a case of acute liver damage associated with saw palmetto. A 58-year-old man consumed a commercially available $S$. repens (2 capsules/day) as a treatment of BPH. He was previously diagnosed with Gilbert's syndrome, the most common hereditary cause of increased bilirubin present in 5-10\% of the population due to reduced activity of the enzyme glucuronyltransferase, which conjugates bilirubin and some other lipophilic molecules. Gilbert's syndrome produces an elevated hematologic level of unconjugated bilirubin but normally has no serious consequences. After taking S. repens, the patient was diagnosed acute liver injury. According to other case reports, saw palmetto was linked to pancreatitis as well. In 2006, Jibrin et al. (16) reported a case of 55-yearold man who had saw palmetto for four years for BPH. He presented with severe epigastric pain, vomiting, and nausea. The patient was diagnosed with both acute hepatitis and pancreatitis due to saw palmetto. Bruminhent et al. (36), reported another case of acute pancreatitis following exposure to $S$. repens. A 61-year-old man with previous history of BPH and gastro-esophageal reflux disease developed acute pancreatitis resulting from saw palmetto ingestion with other drugs.

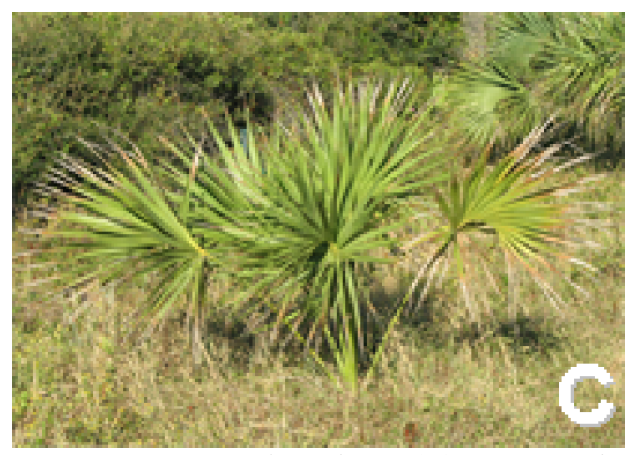

Figure 2: Hepatotoxic Plant (C) Saw palmetto (Serenoa repens) (42)
Comfrey (Symphytum officinale L.):

Comfrey is a common garden plant that belongs to Boraginaceae family (43). There are several species that belong to Symphytum genus, which includes $S$. officinale L. (comfrey), S. asperum Lepech, S. caucasicum Bieb, S. tuberosum L. and S. $x$ uplandicum Nyman $(43,8)$. The most commonly used species is S. officinale L. or comfrey, which is a long perennial plant that is made of small flowers that are purple in color and large hairy leaves $(44,45)$ (Figure 2D). For more than 2000 years, comfrey leaves and roots have been used as medicinal herb (46). Additionally, comfrey has been consumed as tea and vegetable for the treatment of various diseases including bone fractures, wound healing, inflammation of joints, and thrombophlebitis $(47,48)$. The major content of comfrey is pyrrolizidine alkaloids (PA), which is presented in higher concentration in roots than in leaves (49). Several studies reported health risk associated with PA. The major hepatotoxic effect of PA is the hepatic venoocclusive disease (VOD) $(50,51)$ that is also known as Sinusoidal obstruction syndrome (52). Portal hypertension with severe ascites is one of major characteristics of VOD disease (53). Epidemics of VOD were reported several decades ago in South Africa, Jamaica and India and Afghanistan (8). In a case report previously published by one of the authors (CS), bush tea containing pyrrolizidin alkaloids was consumed by the mother of a baby who presented at neonatal age with VOD and liver failure (54). This was the youngest patient with VOD ever described in the literature. Many case reports confirm indeed the toxicity associated with comfrey consumption. The first report of PA intoxication was in 1985 (50). A 49-year-old woman was diagnosed with portal hypertension with obliteration of small hepatic venules after taking $85 \mathrm{mg}$ of PA for six months. Another recent case involved a 66-year-old woman that was previously diagnosed with chronic disease. She consumed around $1.5 \mathrm{~L}$ of comfrey tea, which caused progressive dyspnea. Subsequently, she developed severe pulmonary hypertension (55). Using comfrey leaves as vegetarian diet, a 23year-old man reported to have VOD with severe portal hypertension and lastly died due to liver failure (56). Another case was a 47-year-old woman, who consumed ten cups of comfrey tea (10 cups daily) as well as comfrey pills for more than one year. After four years, she was diagnosed with ascites and her liver biopsy showed dense fibrosis of portal tracts as well as bile duct proliferation around the portal tracts of the liver 
(57). Cases of comfrey-induced hepatic VOD were reported in young ages and infants beside older age patients. One case report of 13-year-old boy drank comfrey tea (unknown quantity) for his Crohn disease. Liver biopsy was done because of hepatomegaly and ascites resulted in hepatic VOD (58). Another case report of 18-month-old boy showed the evidence of comfrey-induced VOD in infants drinking comfrey herbal tea (53).

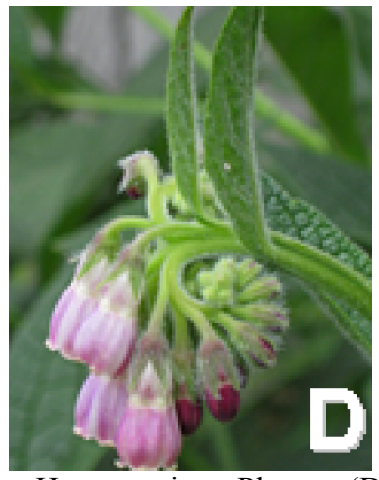

Figure 2: Hepatotoxic Plant (D) Comfrey (Symphytum officinale L.) (59)

\section{Germander (Teucrium chamaedrys $L$.):}

Teucrium chamaedrys L., also known as wall germander, is a small herbaceous, perennial and aromatic plant that belongs to the Lamiaceae family (Figure 2E) $(5,60)$. Germander belongs to the East Mediterranean basin and found in all European woods $(60,61)$. Since ancient times, germander has been used as herbal remedy for several properties including antiseptic, antidepressant, diuretic, choleretic, and tonic (5, 17, 60). Globally, wall germander has been used as capsules or teas for the treatment of obesity and as a weight-loss agent $(13,17,60)$. Moreover, germander was considered safe until many cases of hepatotoxicity associated with germander ingestion were reported in France $(62,63)$. Other side effects of germander include nausea, vomiting, anorexia, and jaundice $(63,64)$. Teucrium chamaedrys $L$. contains many chemical substances including glycosides, saponins, neoclerodane diterpenoids, and flavonoids $(5,13,60)$. Neoclerodane diterpenoids are the major chemical compound that may cause liver injury. Additionally, the hepatotoxicity may also be attributed to Teucrin A and teuchamaedryn A, which are components of the diterpenoids fraction $(13,63,65)$. In 1992, the germander powdercontaining capsules were prohibited and banned from the French market after an epidemic of 30 cases of hepatitis (13). Several case reports have reported the hepatotoxic effect associated with germander ingestion $(5,13,17,60)$. Larrey et al reported seven cases of acute hepatitis after germander ingestion (17). One of the cases involves a 54-year-old woman, who was taking germander capsules for weight loss and developed hepatitis. However, after six months of germander discontinuation, the women showed a complete recovery of the liver function. Larrey et al. also reported another case with hepatitis. A 15-yearold female adolescent, who had abdominal pain and developed hepatitis with jaundice after taking germander capsules $(600 \mathrm{mg}$ /day) for few months in combination with other drugs. She recovered after one month of germander discontinuation (17). Laliberte et al. (5) reported two cases of germander-induced hepatitis. The first case is a 55-year-old woman with no history of liver disease who took germander capsules (1600 $\mathrm{mg} /$ day) as a medication for hypercholesterolemia with some other drugs. She developed jaundices after six months of germander intake and diagnosed with hepatitis. However, the liver function tests of the patient improved after two months germander was discontinued. The second case involved a middle-aged woman used germander $(260 \mathrm{mg} /$ day) for 6 month to reduce her weight and was diagnosed with jaundice, asthenia, and hepatitis. Additionally, there is a case of 68-year-old woman who developed massive hepatic necrosis following ingestion of $450 \mathrm{mg}$ daily of wild germander for two weeks (66).

\section{Kava (Piper methysticum):}

Kava, which is also known as ava, intoxicating pepper, awa, kava pepper, kawa, kava root, kawa, and kew, is a tropical shrub plant that belongs to the Piperaceae family (Figure $2 \mathrm{~F}$ ) $(18,68,69)$. It has been traditionally used for centauries in South pacific Islands (Hawaii, Polynesia and fidji) for ceremonial proposes and as a remedy for psychotropic conditions $(70,71)$.

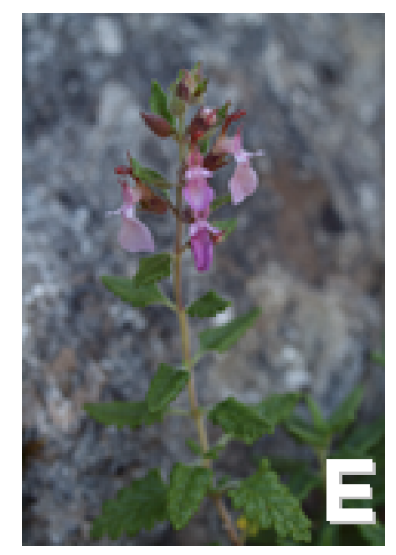


Figure 2: Hepatotoxic Plant (E) Germander (Teucrium chamaedrys L.) (67)

For more than 2000 years, south pacific Islanders used kava-kava drink from kava plant without known side effect (72). Moreover, kava has been used by Western as an alcohol replacement to reduce anxiety and give relaxation feeling and as a treatment for sleeplessness, menopausal symptoms and depression (70,73). Rhizomes and roots of kava plant were the most used parts for their psychoactive properties that include sedation, anxiolysis and relaxation (74). Accordingly, the most active constituent of kava is kavalactones or kavapyrones, which is present in high concentration in roots. Kava lactones involve six major lactones (kavain, dihydrokavain, methysticin, dihydromethysticin, yangonin, and desmethoxyyangonin), which are responsible for pharmacological activity in humans (75). Even though kava known to have no side effects in the past, the first report of its side effects were reported in Europe (76). Moreover, hepatotoxicity associated with kava ingestion was also reported in Germany when 24 cases were diagnosed with severe liver injury (73). Whitton et al (73) indicated that the toxicity of kava was due to the extraction methods of lactones and posology of this natural product. Several cases reported the severe hepatotoxicity of kava leading to hepatitis, hepatic necrosis, and cholestatic hepatitis (70). Humberston et al (68) reported a case of acute hepatitis associated with kava-kava ingestion in a 14-year-old girl. A liver transplantation was performed and she recovered. $\mathrm{Fu}$ et al. (18) reported another case of kava hepatotoxicity. A 45-year-old woman took kava as one tablet twice a day for 8 month and she was diagnosed with jaundice and hepatitis. The patient required liver transplantation and she recovered later. More reported cases of kava-associated hepatotoxicity came from Europe. Six patients were women aged between 22 and 61 years and two patients were men with age between 32 and 50 years took kava (60 mg- $240 \mathrm{mg} /$ daily). They all required liver transplantation after they were diagnosed with fulminant hepatic failure (76-78). Another case of kava-associated hepatotoxicity involved a 50-year-old female, who had hepatic necrosis when she had $210 \mathrm{mg} /$ day of kava for four months. The woman had a liver failure however, she lived after liver transplant once performed (79). There are some other cases with patients, who unfortunately did not survive (77).

Greater celandine (Chelidonium majus L.): Greater celandine is a plant that belongs to
Papaveraceae family. It is an important herb for its therapeutic potential and it grows widely in

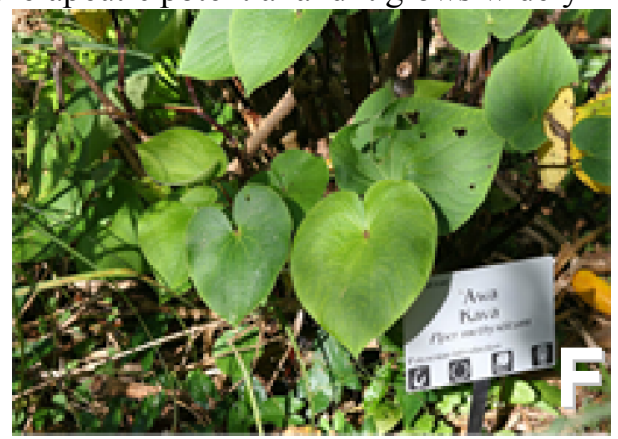

Figure 2: Hepatotoxic Plant (F) Kava (Piper methysticum) (80)

Europe and Asia (81). Some common synonyms are swallow-wort and bai-qu-cai (82). The dried aerial parts of greater celandine are used as a treatment for gastrointestinal tract disorders (81). Greater celandine extract has been used as a therapy for jaundice, cholelithiasis and biliary colic (83). Additionally, it is known to have spasmolytic and alleged choleretic properties (84). The whole plant found to have several different alkaloids; however, the main alkaloids are benzophenan thridines and protoberberines. Other common alkaloids are hydroxycinnamic acid derivatives (81). The potential hepatotoxicity of greater celandine has been reported in several case reports. Accordinglly, analysis of case reports of 21 patients (18 females aged between 22-67 year-old and 3 males aged between 58-69 year-old) showed the causality of hepatotoxicity induced by greater celandine (85). There were high causality levels for greater celandine in two patients and low levels in 13 patients, where in the other 6 patients the causality was probable. Furthermore, this assessment of case reports associates the use of greater celandine preparation with liver injury. Stickel et al. (84), provided two cases of hepatotoxicity linked with $C$. majus. The first case involved a 39-year-old female who diagnosed with impaired hepatic synthetic function after ingestion of greater celandinecontaining product as well as sulfamethoxazole antibiotic and penicillin.

However, the patient fully recovered after discontinuation of the herbal preparation. The second case involved a 69-year-old man developed cholestatic hepatitis after intake of greater celandine-containing drug for 6 weeks for his abdominal discomfort. The patient completely recovered. Moro et al. (81), reported another case of $C$. majus inducing hepatotoxicity. A 65-yearold man drank a cup per day of greater celandine 
for a month with lansoprazole medication for his bacterial infection. He developed acute cholestatic hepatitis with high levels of transaminase and bilirubin, but he recovered completely after withdrawal of both drugs. Additionally, a 37-yearold woman diagnosed with cholestatic hepatitis after ingestion of several herbal preparations including greater celandine for 3 months for her atopic eczema. The woman stopped taking greater celandine but continued with other medications and she recovered (86). Moreover, greater celandine showed to cause phototoxicity and cytotoxicity on cancer cells $(87,88)$.

\section{Atractylis gummifera:}

A. gummifera is an herbaceous and thorny plant (Asteraceae family) that belongs to Mediterranean countries $(30,89)$. It is also known as blue thistle, bird-lime, chamaelon, acarna gummifera and carlina gummifera L. $(89,90,91)$. A glue-like substance with whitish-yellowish color is secreted from this plant. A. gummifera root extract is commonly used as antipyretic, diuretic, emetic and purgative as well as chewing gum $(92,93)$. However, it is a well known life-threatening poisoning (89). The intoxication with $A$. gummifera was first described by Lefrane since 1866 (90). The major toxic constituents are two diterpenoid glycosydes: atractyloside (ATR) and carboxy-atractyloside (CATR) (90,91). Several case reports of $A$. gummifera inducing toxicity were reported and most victims were children because of sweet taste of the juice of this herb (94). One case report reported intoxication associated with consumption of A. gummifera rhizome in two children aged 4 and 6 . They both presented with vomiting, abdominal colic, cyanosis as well as coma. They were diagnosed with congested intestine and had haemorrhages in stomach and kidney. The following morning, both children died (91). Another case of 7-year-old boy presented with vomiting and epigastric pain after drinking A. gummifera extract for treating oxyuriasis. The boy's condition worsened and died (95).

\section{Impila (Callilepis laureola):}

C. laureola is an herbaceous perennial plant that belongs to Compositae family (96). It is native to KwaZulu-Natal region of northeast of South Africa (97). C. laureola is commonly known as Impila that means "health" in Zulu (97). Impila has been traditionally used as a remedy for stomach problems, infertility, cough and worm infection (96). Additionally, C. laureola was used to word off the evil spirits (98). It is known to be highly toxic and very poisonous plant that is responsible for several deaths (99). Similar to $A$. gummifera , $C$. laureola contains toxic atractyloside (100). In South Africa, C. laureola has been linked with some cases of hepatitis and renal tubular necrosis (101). Moreover, an analysis of 50 children with Impila intoxication was done (102). The age of children ranged from 0 to 12 years and they were diagnosed with hypoglycaemia, hepatic dysfunction, renal dysfunction and alteration in consciousness level. Another case involved a mother (21-year-old) and her daughter (1-year-10-month-old) who consumed Impila and developed a toxic reaction. The mother died due to hepatocellular necrosis whereas the child recovered (98).

\section{Chinese Herbal Remedies:}

Chinese Herbal Medicine (CHM) has been known for more than 4000 years and was first found by Dhen Nung (103). CHM has been extensively used for centuries as a treatment for different diseases and conditions (104). However, the use of Chinese medicine raised serious concerns regarding safety due to unknown composition and amount of plants used (94). There are several hepatotoxicity effects have been associated with different Chinese herbal remedies. Moreover, the toxicity of CHM can be attributed to either one or several components (94). One of the commonly used herb in China is Jin Bu Huan (Lypocodium serratum), which has been used for centuries as analgesic, sedative and sleeping aid (30). Accordingly, Jin $\mathrm{Bu}$ Huan (JBH) reported to cause various hepatotoxic events $(94,105)$. It contains a single active constituent that is the extract of Lycopodium serratum $(94,106)$. Additionally, three females were diagnosed with acute hepatitis after consumption of JBH that was purchased from the same store (105). The first case involved a 66-year-old female who consumed 2 tablets (three times per week) as a treatment for her back pain and insomnia. The second patient (24-year-old) used JBH as a treatment for her insomnia (four times per week). She presented with jaundice, excoriations of her limbs and tender hepatomegaly. The last case involved a 45-year-old female presented with tender hepatomegaly and used JBH from three to four times per week for her insomnia along with another herb called "Ma Huang". Moreover, all the patients recovered after discontinuation of herbal preparations. Another hepatotoxic effect of JBH involved a 49-year-old male diagnosed with chronic hepatitis as well as moderate fibrosis after ingestion of three tablets of JBH per day (107). 
His liver function tests returned to normal after discontinuation of JBH. Additionally, a case of 7 patients aged between 24-66 years old who used JBH and presented with fatigue, vomiting, nausea, fever and jaundice. They took from 2 to 6 tablets of JBH weekly (2-7 times) for treating insomnia, back pain and arthralgia. The all developed acute hepatitis due to JBH intake (108). Another common Chinese herbal remedy is Ma Huang, which is a product that derived from the aerial parts of Ephedra sinica plant that found in Mongolia and China $(109,110,111)$. Ma Huang is known in English as "Yellow astringent" and has been traditionally used in China for the treatment of bronchitis and cough and as a slimming aid $(109,112,113)$. Additionally, this medicinal herb has been used to enhance energy levels (110). Despite the prolong use of Ephedra in Chinese traditional medicine; it has been linked to many serious hepatotoxic effects $(110,111,114,115)$. The major constituent in Ma Huang that is responsible for toxic effects is Ephedrine (110). Accordingly, Ephedrine showed to cause severe acute hepatitis in 33-year-old woman who used Chines herbal medicine containing Ma Huang (110). Another hepatotoxic case associated with Ma Huang consumption involved a 28-year-old man who had Ma Huang for 2 month for bodybuilding. He developed hepatitis and recovered after discontinuation of herbal product (114). Ma Huang hepatotoxicity was seen in 44-year-old man who had over the counter drug called "Hydroxycut" for weight loss (3 capsule for 4 months). The man developed toxic hepatitis due to Hydroxycut, which found to contain Ma Huang extract. However, the patient recovered after cessation of the drug (115). Moreover, a 61-year-old man drank Ma Huang infusions and presented with hepatorenal syndrome as well as several thromboembolic conditions (116). Another case of Ma Huang related hepatotoxicity involved a 57-year-old woman who took two Chinese herbal products (one contains Ma Huang) for the treatment of sinusitis. The woman developed jaundice and acute liver failure and recovered after liver transplantation was done (109). Additionally, Ma Huang has been associated with high blood pressure and high heart rate in 42-year-old male who took E. sinica along with Saw palmetto and multivitamins for bodybuilding (117). The patient was diagnosed with hypertension and tachycardia due to ingestion of this herbal product. Lastly, a 23-year-old male student found dead in his apartment after consumption of Ma Huangcontaining drink once or twice per day for more than 6 month (118). Moreover, Shou-Wu-Pian is another common Chinese herbal mixture. ShouWu-Pian preparation is formulated from the root of Polygonum multiflorum plant (fleece flower root), which is a common Chines herb that belongs to Polygonaceae family $(113,119)$. ShouWu-Pian is alternatively known as He-Shou-Wu and Mr. Black Hair $(119,120)$. The roots and vines of $P$. multiflorum have been used as a tonic for treating several conditions including backache, constipation, dizziness, greying of hair, spermatorrhea, lumbago and treating symptoms of chronic prostatitis $(120,121,122)$. Shou-Wu-Pian has been well known for its association with longevity and youthfulness (120). Furthermore, several cases of hepatotoxicity associated with Shou-Wu-Pian consumption have been reported $(112,121,123,124)$. The Shou-Wu-Pian hepatotoxicity has been attributed to its toxic constituent, anthraquinone (120). One of the reported hepatotoxic cases involved a 46-year-old woman who had an acute hepatitis after ingestion of Shou-Wu-Pian for greying of hair. She recovered after discontinuation of the herbal medicine (120). Another 53-year-old woman had toxic reaction due to Shou-Wu-Pian consumption and developed acute hepatitis. She also recovered after cessation of the herbal product (125). Additionally, Panis et al (119) reported the first case of Shou-Wu-Pian inducing hepatotoxicity in pediatric. A 5-year-old girl presented with acute liver injury twice related to Shou-Wu-Pian product. Another reported case of hepatotoxicity involved a 17-week pregnant woman who consumed Shou-Wu-Pian for treating hair loss. She presented with jaundice and diagnosed with acute toxic hepatitis (119). Moreover, a 78-yearold male used Shou-Wu-Pian for the treatment of chronic prostatitis and developed acute hepatitis. The patient recovered after discontinuation of the herbal medicine (121). Additionally, Dictamnus dasycarpus is another botanical that presents in Chinese herbal mixture (126). It belongs to Rutaceae family and has been used as a remedy for skin diseases, cough, jaundice and rheumatism (127). D. dasycarpus has been linked with some hepatotoxic events as well as death $(10,128,129,130,131)$. One case of hepatic injury involved a 49-year-old female presented with itching and jaundice after drinking a mixture of Chinese herbal tea for her eczematous skin disease. Hepatomegaly and elevated liver enzymes were presented and the patient was diagnosed with reversible acute hepatitis due to intake of Chinese herbs. The analysis of Chinese mixture showed the presence of couple of 
botanicals including D. dasycarpus (128). Another case of Chinese mixture toxicity involved 51-year-old male who previously had psoriasis and took a mixture of Chinese herbs daily for 8 weeks. His liver function tests were substantially elevated and he died (129). Moreover, a 61-year-old female took Chinese herbal preparations for 11 months as a remedy for eczema. The patient presented with jaundice, malaise, nausea, and weight loss. Her Chinese mixture found to contain a constituent of $D$. dasycarpus (130). Another case of a 39-year old female presented with anorexia, fatigue and nausea after ingestion of mixture of Chinese plants daily for 2 months to treat her psoriasis. The Chinese mixture found to contain $D$. dasycarpus as one of herbs (130).

\section{Kampo Medicine:}

Kampo medicine is a Chinese medicine that has been produced in Japan and it is a mixture of several herbs (111). Dai-Saiko-to or TJ-8 is a kampo formula that consists of seven herbs and used for the treatment of dyspepsia, fever, gallstones, fatigue, and chronic hepatitis $(10,132)$. However, some reports reported cases of hepatotoxicity associated with consumption of Dai-Saiko-to. One case of hepatotoxicity included a 55-year-old female who took Dai-Saiko-to for 3 weeks and presented with fatigue, fever and increased liver enzymes. She was diagnosed with autoimmune hepatitis (132). Another case involved a 65 -year-old man who ingested a $7.5 \mathrm{~g}$ of Dai-Saiko-to with other herbs included Shohusan and Hange-shashin-to for 7 weeks for treating his dermatitis. The patient presented with dyspnea and diagnosed with hepatic injury due to herbal preparation (10). Accordingly, the toxic agents presented in Dai-Saiko-to could be attributed to glycyrrhiza and scutellaria constituents (132). Another kampo herb is Syo-saiko-to, which has been used as a therapy for pyretic diseases and liver diseases in Japan, Taiwan, and China. It is also known as Xiao-chai-hu-tang or da-chai-hutang in China and TJ-9 in Japan $(10,111,113,133)$. Syo-saiko-to consists of seven different botanicals including Scutellaria and Glycyrrhiza (111). Accordingly, some cases of hepatotoxicity have been reported due to intake of Syo-saiko-to. Four cases of four females aged between 42 and 58 had $7.5 \mathrm{~g}$ of Syo-saiko-to for up to 7 weeks as a therapy for acute hepatitis (134). They all presented with jaundice and diagnosed with inflammation of portal tract, fibrosis, microvesicular fatty change, acidophilic degeneration and two of them developed cholestasis. The toxic compound in Syo-saiko-to for these cases found to be bicalin in Scutellaria and glycyrrhizin in Glycyrrhiza (133). Moreover, Syo-saiko-to showed to contain glycyrrhizin-a triterpenic saponoside- that causes liver diseases including fatal hepatic necrosis, hepatic granulomas and microvesicular steatosis (113).

\section{Kombucha "mushroom" Tea:}

Kombusha tea is a health drink that made by the fermentation of sweetened black tea with kombucha fungus, which is a symbiotic yeastbacteria aggregate that surrounded by a permeable membrane $(135,136)$; which is not a real mushroom (136). Kombusha has other synonyms such as Manchurian mushroom tea, Manchurian fungus tea or Kargasok tea $(113,135)$. This healthy beverage has been used as therapy for several conditions like treating cancer, increasing $\mathrm{T}$ cell count, lowering blood pressure, curing arthritis, treating gastrointestinal disorders and alleviating constipation $(135,136)$. Kombusha tea is also known as "fountain of youth" tonic as it restores the gray hair, reduces wrinkles and treats acne $(136,137)$. However, kombusha beverage has been associated with several cases of hepatotoxicity and other side effects $(135,138,139)$. A case of hepatitis due to intake of Kombusha drink was reported in a 53-year old professor (137). He drank the preparation as a half cup twice a day for two weeks that advised by his friend for treating his hypothyroidism and fibromyalgia conditions. However, he recovered after discontinuation of the Kombusha drink. Moreover, two females (59 and 48-years-old) reported drinking Kombusha beverage. The first patient had $4 \mathrm{oz}$ daily for 2 months and developed sever metabolic acidosis and died. The second patient increased amount of tea from 4 to $12 \mathrm{oz}$ daily for 14 days and developed acute pulmonary edema and sever metabolic acidosis. Additionally, the patient had cardiac arrest but her health improved (138). Another case of Kombusha toxicity involved a 22-year-old male who diagnosed with HIV and decided to use Kombusha tea as it known to increases the $\mathrm{T}$ cell count (139). The patient developed acute renal failure as well as hyperthermia and lactic acidosis after 12 hours of Kombusha intake. Furthermore, two females aged 55 and 51 drank Kombusha tea to improve their health; the first patient developed jaundice and second patient had breathing shortness, akathisia and shaking (135). Additionally, two men aged 53 and 83 drank Kombusha tea as one-half cup daily for 3 weeks and developed transaminitis (139). However, both 
patients recovered after cessation of the beverage. The exact toxic agent of Kombusha mushroom is unknown but it showed to have usnic acid that is derived from lichen $(106,113)$. However, its toxic reaction could be due to contamination of the tea. Moreover, preparation and storage of Kombusha tea must be made in glass containers as lead and ceramic can leach toxic components into preparation (140). Two cases of symptomatic lead poisoning due to Kombusha tea have been reported in one couple. They both drank Kombusha tea in ceramic container, which was covered by glaze made of lead (139).

\section{Senna (Cassia angustifolia):}

C. angustifolia, commonly known as Senna or Tinnevelly, is a plant that is native to Arabia and belongs to Fabaceae family $(141,142)$. The leaves (pods) and fruits of senna have been used as laxative in form of herbal tea $(141,142)$. However, excessive abuse of $C$. angustifolia has been implicated in few cases of hepatotoxicity. Accordingly, a 26-year-old female was diagnosed with toxic hepatitis after intake of herbal tea containing $10 \mathrm{~g}$ of senna leaves and $100 \mathrm{mg}$ of sennoside B (extract of senna fruit) twice a week (143). Another case of senna hepatotoxicity involved a 52-year-old woman who drank $1 \mathrm{~L}$ of herbal tea containing $70 \mathrm{~g}$ of Senna dried fruit for more than 3 years. The patient developed acute liver failure with renal impairment due to chronic use of $C$. angustifolia (141). Moreover, a 42year-old female presented with epigastric pain, vomiting and intermittent fever after intake of 200 $\mathrm{ml}$ of dried senna leaves for 2 years. The patient was diagnosed with portal vein thrombosis (PVT) (142). Another case of subacute cholestatic hepatitis has been reported in 77-year-old male. The patient admitted taking Senna for the treatment of constipation (144). Additionally, chronic use of $C$. angustifolia has been associated with serious conditions like chronic diarrhea and loss of fluid and electrolyte (141). Furthermore, cases of sever hepatic damage associated with Senna are rare. The hepatotoxic effect of Senna can be ascribed to its major constituent, sennosides, which are present in leaves and fruits. Sennosides split to rhein anthron that resemble hepatototoxic danthron $(93,141,143)$. Anthraquinone glycosides also present in senna, which are suspected to cause hepatic diseases as well $(100,143)$.

\section{Pennyroyal oil:}

Pennyroyal oil, which is also known as squawmint oil, is derived from two plant species
Hedeoma pulegoides and Mentha pulegium $(100,145)$. It has a mint-like odor and it has been used as insect repellent and abortifacient since Roman times $(146,147)$. Pennyroyal oil has been used as a treatment for cold, menstruation and to purify blood $(148,149)$. Additionally, it has been used as a therapy for upper respiratory tract and ear infections (149). However, sever cases of hepatotoxicity associated with pennyroyal oil ingestion have been reported (150). A small amount of oil (10-15 ml) can cause sever toxicity like liver and lung damage and can cause death as well $(148,149)$. The primary constituent of pennyroyal oil is pulegone and it contains some other monoterpenes such as neomenthone, menthone and iso-menthone (149).

Accordingly, one case of pennyroyal oil toxicity involved an 8 week-old boy who drank around $120 \mathrm{ml}$ of tea made from mint plant that contains toxic pennyroyal oil. The infant had fulminant liver failure with cerebral edema caused by menthofuran constituent of pennyroyal oil. $\mathrm{He}$ died shortly after initial symptoms appeared (150). Another case involved a 6 month-old boy who took aspirin and $90 \mathrm{ml}$ of tea (3 times per week) from home grown mint plant for his congestion and colic. The baby had hepatic dysfunction with sever epileptic encephalopathy. The plant found to contain both menthofuran and pulegone (150). Additionally, 24 year-old women took both pennyroyal extract and black cohosh root for induction of abortion. She continued taking pennyroyal and black cohosh with unknown amount and she died (149). Anderson et al (149) reported two cases of pennyroyal oil toxicity in two women who drank a preparation of pennyroyal tea to induce menses. The first woman developed dizziness and weakness after ingestion of tea and recovered later. The other woman had mild abdominal cramps; however, she drank more of the tea because the menses did not start and developed sever abdominal cramps and nausea. After 5 days the menses occurred and she recovered. Some studies showed that Nacetylcysteine provides a protection against pennyroyal inducing hepatotoxicity $(30,150)$.

\section{Margosa oil (Azadirachta indica):}

Margosa oil, yellowish oil with disagreeable taste and smell, is extracted from Neem tree seeds that are native to India (151). Margosa oil or Neem oil is usually given to infants in India, Thailand, Indonesia and Sri Lanka to maintain good health. The oil contains volatile sulphor compounds, fatty acids as well as bitters like nimbin, nimbidin, nimbinin and nimbidol, which are responsible for 
its toxicity (151). Accordingly, hepatotoxicity of neem oil resembles Reye's like syndrome, which characterizes by mitochondrial toxicity, microvesicular steatosis and depletion of hepatic ATP and glycogen stores (93). One case of neem poisoning that resembles Reye's syndrome has been reported in an infant. The liver biopsy of this infant showed fatty infiltration of liver, proximal renal tubules and cerebral edema (152). Two cases of encephalopathy caused by margosa oil poisoning in infants have been reported (151). A 5 -month-old boy given $5 \mathrm{ml}$ of oil after drinking milk presented with generalized convulsions and loss of consciousness. The second patient was a 3month-old girl who had few drops of oil presented with generalized convulsions. Both babies recovered. Furthermore, Sinniaf et al $(152,153)$ reported Reye-like syndrome due to intake of Margosa oil in 13 infants and children. Another case of Neem oil poisoning involved a 5-year-old boy who developed a neurodeficit due to accidental intake of Margosa oil (154). Moreover, Neem oil reported to cause renal tubular acidosis in 51-year-old man after consumption of large amount of oil (155). The patient was also diagnosed with hepatotoxicity, anemia, encephalopathy and coagulopathy.

\section{St. John's Wort (Hypericum perforatum):}

Hypericum perforatum is an herbaceous perennial herb that is indigenous to Europe (156). The aerial part of this herb is used for the preparation of St. John's Wort (SJW) extract that has been traditionally used for more than 200 years as a remedy for wide spectrum of medical illnesses such as insomnia, bronchitis, burns, gastritis, hypothyroidism, insect and snake bites, scabies and cancer $(156,157,158)$. Mainly, SJW has been used as an anti-depressant remedy and became one of the top selling anti-depressant agents $(156,158)$. H. perforatum has been known to interact with numbers of drugs, which can be beneficial like increasing response of clopidogrel and reducing toxicity of irinotecan (159). However, SJW raised concerns regarding its lifethreatening interaction with other conventional drugs including cardiovascular (Digoxin), oral contraceptives, immunosuppressants (Cyclosporin), chemotherapeutics (Irinotecan), anti-depressants (Amitriptyline), anti-diabetics (Gliclazide), anti-androgenics (Finasteride), antiretrovirals (Indinavir), benzodiazepines and statins $(111,158,159,160)$. Particularly, these drugs are substrates of either cytochrome $\mathrm{P} 450$ or P-glycoprotein (156). Moreover, interactions of SJW with other drugs reported to cause sever consequences involving the reduction of blood cyclosporine levels, reduction of plasma levels of anticancer and antiretroviral drugs, causing serotonin syndrome or unwanted pregnancies $(156,159)$. One case involved a 59 -year-old male who presented with hyperlipidemia and initially took pravastatin $(80 \mathrm{mg} /$ day $)$. His medication changed to rosuvartatin $(10 \mathrm{mg} /$ day $)$ due to presentation of hypercholesterolemia. $\mathrm{He}$ admitted taking SJW (300 mg twice/day) as a remedy for insomnia. Accordingly, the total levels of cholesterol and low-density lipoprotein cholesterol level were markedly increased due to SJW-rosuvartatin interaction (161). Additionally, a 29-year-old female underwent cadaveric kidney and pancreas transplant and had been on cyclosporine $(100 \mathrm{mg})$ twice a day as well as $H$. perforatum extract $(300 \mathrm{mg})$ twice a day for up to 8 weeks. The patient presented with reduced plasma cyclosporine concentrations due to interaction between SJW and cyclosporine drug (162). Another case of SJW-drug interaction is presented in a 36-year-old patient who received a liver transplant due to cirrhosis. The patient took a cyclosporine drug $(175 \mathrm{mg})$ twice a day with $H$. perforatum tablets $(900 \mathrm{mg})$ twice a day as an anti-depressant. The patient developed severe acute rejection as well as reduction of cyclosporine level (163). Another case of SJWdrug interaction has been reported in a 41-yearold female diagnosed with disorganized schizophrenia. She took clozapine $(500 \mathrm{mg} /$ day $)$ for 6 months accompanied with SJW extract (300 mg three times/day). The clozapine plasma concentration was reduced and disorganization was increased in the patient due to SJW-clozapine interaction (164). Moreover, SJW consists of several pharmacological active constituents but the main ingredient is hyperforin, which is suspected to cause SJW-drug interaction $(156,157)$. Another important ingredient of SJW is hypericin, which can cause some of herb-drug interaction events (159). Moreover, Hyperforin showed to interact with many neurotransmitters such as serotonin, dopamine, gammaaminobutyric acid, glutamate and noradrenaline (156).

\section{Valerian (Valeriana officinalis):}

Valeriana officinalis is a plant (Valerianaceae family) that is indigenous to North America, Europe and Asia (165). The dried root of $V$. officinalis is known as valerian, which has been used for long time by ancient Rome and Greece as sedative and anti anxiety remedy and for treating insomnia $(165,166)$. Additionally, it has been used as a remedy for treating palpitation, 
headache, gastrointestinal pain, high blood pressure, sleeping disorders and menstrual cramps (166). Valerian is a common herb and found in many over the counter preparation either alone or combined with other herbs (167). Some hepatotoxic events associated with valerian ingestion have been reported. The first cases of valerian-induced hepatotoxicity were reported in 1989, where 4 patients took over the counter sleep aids containing valerian (168). Another case of valerian hepatotoxicity was described in a $27-$ year-old female took 1 capsule of valerian root extract for 3 months and developed hepatic inflammation. She recovered after discontinuation of herbal preparation (165). Moreover, valerian showed to have an interaction ability with other botanicals and can cause a sever injuries (169). Accordingly, a 43-year-old woman who ingested valerian with skullcap and black cohosh and some other herbal preparations developed hepatitis (14). MacGregor et al. (168) described four cases of herb-herb interaction causing hepatic injury. Four women aged between 41 and 57 developed acute hepatitis after consumption of two herbal medications (Kalms and Neurelax) for stress relief. Later studies showed that Kalms contains valerian and skullcap as well as some other herbs where Neurelax contains skullcap only.

\section{Mistletoe (Viscum album):}

Mistletoe is a woody perennial plant that belongs to Loranthaceae family and grows on oaks and other trees (170). It is native to Asia, Europe and England (170,171). Some synonyms of mistletoe are all-heal, bird lime mistletoe, bird lime, European mistletoe, and viscum (170). Helixor, Iscucin, Iscador and Plenosol are trade names of mistletoe (171). All mistletoe parts have been widely used as a treatment for several conditions including hypertension, headache, insomnia, epilepsy, asthma, infertility, cancer and urinary disorders $(30,171)$. Accordingly, mistletoe found to have potential toxic constituents including $\beta$ phenylethylamine, acetylcholine, tyramine and propionylcholine (172). It also contains lectins and viscotoxin that cause several side effects such as hypertension, chills and fever (170). The hepatotoxicity related to mistletoe consumption is rare and only few cases have been reported (111). One case report involved a 49-year-old woman presented with general malaise, nausea and dull ache in the right hypochondrium. She admitted taking herbal medication containing Mistletoe, skullcap, motherwort and kelp for her nervous tension and she developed acute hepatitis (172).

\section{Skullcap (Scutellaria baicalensis):}

Scutellaria baicalensis is an herbaceous herb that belongs to mint family and has two species. The first species is $S$. baicalensis that is alternatively known as Chinese skullcap, Baikal skullcap or Huang-qin and commonly used in Chinese medicine. The second species is S. lateriflora that also known as blue skullcap, hoodwort or Virginian skullcap that is native to Americans $(173,174)$. Scutellaria has been used as a sedative and anti-inflammatory agents (106) and for treating several ailments like cancer, jaundice, hepatitis, anxiety, nervous tension, hysteria and epilepsy $(168,175,176)$. Both species includes terpenoid compounds, which can cause hepatotoxic effects (111). Several case reports of hepatotoxicity after skullcap ingestion either alone or in combination with other botanicals have been reported (173). One case report of 28year-old man developed fulminant hepatic failure with multiple sclerosis after congestion of skullcap (6 tablets/ day) with pau d' arco and Zinc. The patient required liver transplantation and died shortly after the liver transplant. He was diagnosed with veno-occlusive disease and fatal hepatic failure due to contamination of herbs with toxic plants (176). Another case involved a 78year-old woman who took one herbal supplement called "Move Free Advanced" with multivitamins daily for treating arthritis. The woman presented with significant cholestasis and hepatitis; however, she improved after discontinuation of herbal medicine. Move Free Advanced supplement found to contain Chinese skullcap and black catecho (173). Another case of skullcap hepatotoxicity included a 77-year-old female who presented with weight loss, anorexia and tiredness. The patient consumed 6 units of alcohol per week. She was diagnosed with hepatitis with pulmonary complication. Later, she admitted taking three herbal preparations, which are BFC (for wasting diseases), Nervine (for anxiety) and Bowel tonic (for peristalsis) three times per day for 6 month. Further investigation reported the presence of skullcap and comfrey in BFC, which caused hepatic injury and pulmonary lesions in the patient (177). Other case reports of hepatotoxicity due to interaction of skullcap with other botanical were mentioned earlier $(14,168,172)$.

\section{Noni juice (Morinda citrifolia):}

Noni juice is derived from Polynesian tropical fruit of Morinda citrifolia tree and it is commonly used in European tabloid press (100). Fruit, roots and leaves of $M$. citrifolia has been used for more 
than 2000 years as a herbal remedy and wellness drink $(178,179,180)$. Additionally, it has ben used for treating many health problems including cancer, AIDS, elevated blood pressure and mental depression $(178,181)$. However, noni juice has been associated with several hepatotoxicity events. The potential toxic constituent of $M$. citrifolia is anthraquinones like moridone, nordamnacanthal, rubiadin, rubiadin-1-methyl ether, anthraquinone glycoside, which are known for their hepatotoxic potential $(180,182)$. According to Stadlbauer et al. (180), a 29-yearold man who previously had acute hepatitis due to paracetamol developed sub acute hepatic failure after consumption of $1.5 \mathrm{~L}$ of noni juice for more than 3 weeks. The patient required a liver transplantation. Moreover, a 62-year-old woman who drank $2 \mathrm{~L}$ of noni juice developed acute hepatitis and recovered after cessation of herbal drink (180). Another case of toxicity associated with noni juice involved a 45-year-old man who had a glass of noni juice daily for few weeks for prophylactic reason. He developed an acute hepatitis and recovered after withdrawal of herbal drink (178). Fulminant hepatitis was reported in 24-year-old female after consumption of noni juice for stimulation of her immune system (182). The patient recovered after discontinuation of the noni drink. Moreover, a 14-year-old-boy drank approximately $600 \mathrm{ml}$ of an antioxidant drink to improve energy and developed acute hepatitis. The drink contains several ingredients including noni berries $(91 \mathrm{mg} / \mathrm{kg})$. However, the boy's health improved (183).

\section{Amanita phalloides:}

One of serious species that causes sever mushroom poisoning is Amanita, mostly $A$. phalloides or death cap $(94,184)$. There are two diverse groups of toxins found in Amanita. The first toxin is phalloidin, which affects enterocytes cellular membrane (184). The second toxin is amanitins mainly $\alpha$ - amanitin, which is absorbed in gastrointestinal tract and can affect liver (184). The later is also responsible for the damage of kidney, pancreas, brain, testes and hematopoietic system. Additionally, death can be resulted from $\alpha$ - amanitin poisoning (94). One case of fulminant hepatic failure after ingestion of $A$. phalloides was reported. A 64-year-old woman presented with vomiting, abdominal pain, diarrhea and nausea after consumption of wild mushroom ( 2 bowl) from her backyard. The patient was diagnosed with fulminant liver failure and required liver transplantation. In this case, the wild mushroom (A. phalloides) found to contain $\alpha$ - amanitin that induced hepatotoxicity (185). Another case of $A$. phalloides poisoning involved a 16-year-old female who presented with vomiting, abdominal pain, diarrhea and nausea. She had wild mushroom and diagnosed with liver failure and required liver transplantation (186). Moreover, four cases of $A$. phalloides poisoning have been reported in children (187). One case involved a 2.5-year-old female presented with diarrhea and vomiting after ingestion of two mushrooms picked by her mother from the woods. The girl had elevated liver enzymes and died due to massive hepatocellular necrosis as well as macrovesicular steatosis. The second case involved an 8-year-old male presented with abdominal pain and nausea after eating fried mushroom. He had elevated liver enzymes and developed renal failure and died due to multiple organ failure. The third case involved an 11-yearold boy who ate fried mushroom collected by his mother from forest and presented with vomiting, nausea and diarrhea. All his family ate from the same mushroom on their breakfast. They all had high liver function tests. The mother died but other family members recovered after treatment including the 11-year-old boy. The last case involved a 10-year-old male presented with vomiting and developed hepatic encephalopathy after eating mushroom that he picked. His condition worsened and required an orthotopic liver transplantation due to development of fulminant liver failure. However, the boy recovered after transplantation. In all four cases, A. phalloides mushroom found to be responsible for mushroom poisoning (187). Moreover, a 72year-old female and her 45-year-old son presented with diarrhea, vomiting and abdominal pain after consumption of wild mushroom picked by themselves. They both had elevated liver enzymes and diagnosed with $A$. phalloides poisoning. They recovered after receiving treatment (188).

\section{Sassafras (Sassafras albidum):}

Sassafras albidum is an aromatic tree, which is native to Eastern North America (189). Sassafras oil that obtained from both root and root bark has been used as flavoring and sudorific agent as well as treatment for insect bites and stings (189). It also used as a therapy of inflammation of eyes, urinary tract conditions and kidney diseases $(145,189)$. The main active constituent of Sassafras oil is safrol (80\%), which is also present in nutmeg, cinnamon, black pepper and mace $(145,190)$. Moreover, it has been found that a small amount of sassafras oil can be toxic to human (191). In 1949, the consumption of large 
quantity of sassafras oil reported to cause neurological effects like hallucinogenic and psychoactive effects (192). In 1960, the FDA banned the use of this oil due to high safrole levels (145). Accordingly, sassafras oil has been classified as a hepatocarcinogen of low grade (192). One case of death in a man who consumed sassafras oil (1 teaspoonful) has been reported (190). The patient used synthetic form of the oil and presented with vomiting, collapse and stupor then died. Additionally, five cases of children aged between 1 and 2.5 years old reported consumption of sassafras oil and presented with several symptoms. All children were vomiting, two were stupor, one had aphasic symptom, one presented with shock sign and three had vertigo signs (190).

\section{Echinacea:}

Echinacea consists of three species that has been used medicinally including $E$. angustifolia, $E$. pallida and E. purpurea $(158,193,194)$. It is a perennial herb that is native to North America and commonly known as purple coneflower $(194,195)$. Other synonyms include black Sampson, black susan, hedgehog, indian head, comb flower and Missouri snake root (136). Echinacea has been used by Plains Indians as a remedy for respiratory infection and fever (194). It also has been used as immune booster and as a therapy of common cold $(169,195)$. Accordingly, Echinacea contains pyrrolizidine alkaloids (PA), which explains the hepatotoxicity associated with it (196). One case of Echinacea hepatotoxicity involved a 45-year-old man who diagnosed with acute cholestatic autoimmune hepatitis due to intake of Echinacea (197). However, no significant hepatotoxicity of Echinacea has been reported. The potential hepatotoxic effect of Echinacea is when taken for more than 8 weeks and with other known hepatotoxic drugs like amiodarone, anabolic steroids, ketoconazole or methotrexate $(193,194)$. Furthermore, there are other known Pyrrolizidine alkaloids-containing herbs that have been associated with hepatic injury as well as death including Heliotropium, Senecio and Crotalaria $(10,93,94,198,199)$. These herbs are common in Africa and Jamaica where intoxication with PA is accidental due to contaminated food (30). In 1992 and 1993, around 4000 individuals had abdominal pain, ascites, alteration of consciousness and hepatomegaly after consumption of grain contaminated with Heliotrpopium lasiocarpum (200). Additionally, four women were diagnosed with VOD after intake of herbal tea containing
Heliotrpopium lasiocarpum in China (201). Senecio species like S. burchelli and S. ilicifolius have been associated with several hepatic diseases $(94,199,202)$. A 5-day-old female infant diagnosed with fatal hepatic VOD (199). The mother used to drink herbal tea daily during her pregnancy with consumption of cannabis and hallucinogenic mushroom. The herbal tea found to contain PA and senecionine. Another case of Senecio intoxication reported in Arizona where two infants diagnosed with VOD (94). Accordingly, several cases of Senecio poisoning have been reported (202). The patients were presented with nausea, vomiting, abdominal pain, accumulation of ascitic fluid and hepatomegaly, which are features of Chiari's syndrome. Moreover, Crotalaria species reported to cause hepatic damage as well (203). In Jamaica, children were diagnosed with hepatomegaly, ascites and cirrhosis after intake of bush tea as a therapy for acute illness. Bush tea found to contain Crotalaria and Senecio (30).

\section{DISCUSSION}

Herbal medicines have been used for centuries and there usage continues to rise worldwide due to the perception that natural products from plants are safer than usual drugs and free of side effects (5). However, severe liver injury has been observed following the consumption of several plant preparations (204). Hence, the liver is the major target of injuries induced by drugs because it is the main organ of drug metabolisms, where foreign chemicals are transformed by metabolizing enzymes including mixed-function monooxygenases, microsomal cytochrome P450 enzymes, UDP-glucuronosyltrans-ferases, sulfotransferases, and glutathione-S-transferases (205). Moreover, botanical-induced hepatotoxicity and liver abnormalities have been extensively documented. Many herbal remedies have been recognized as toxins that cause mild or severe liver damage and some have fatal outcomes (204). In this review, we listed cases of adverse hepatic effects associated with the use of natural medicine and the potential risk of some herbs.

Actea racemosa or Cimicifuga racemosa, which is commonly known as black cohosh, has been widely used as a common treatment of symptoms of menopause among women. It has also been reported to be safe and to improve menopausal symptoms (204-207). Although several studies demonstrated the efficacy of black cohosh as a therapy (208-211), hepatotoxicity 
associated with black cohosh ingestion was reported (205). The concerns regarding the safety of cimicifuga is due to the composition of this plant, which consists of both hepatoprotective and hepatotoxic components (1,14,212,213). Moreover, previous reports have been associated black cohosh with fulminant liver failure (24), autoimmune hepatitis (25), and acute hepatitis (14). Accordingly, the main mechanism of injury of black cohosh is unknown. However, the hepatotoxicity could be attributed to the triterpene glycoside, the major constituent of black cohosh, as well as an immunoallergic mechanism due to presence of tissue eosinophilia $(106,113)$. Another potentially hepatotoxic plant is Larrea tridentate, or chaparral bush, that has been widely used for treating variety of conditions include snakebite, bronchitis and rheumatic pain $(15,29)$. On the other hand, many cases have been reported as a proof of causal relationship of chaparral and hepatotoxicity $(15,32,214-218)$. Accordingly, liver injury associated with chaparral consumption includes acute hepatitis $(31,216,214)$, hepatic fibrosis (31), and hepatic necrosis (32). Some studies linked chaparral toxicity with duration of use as toxicity increases with long duration (219). Additional to hepatotoxicity, chaparral ingestions have been associated with dermatologic and renal toxicity as well (15). The mechanism of action of chaparral toxicity remains unknown (93). However, it could be attributed to its active constituent, nordihydroguaiaretic acid (NDGA), which causes inhibition of lipoxygenase or cyclooxygenase pathways (220), inhibition of cytochrome p450 (221) and chaparral estrogen activity (219). Saw palmetto, the active ingredient in Serenoa repens, is an American dwarf palm tree that is widely used for BPH (222). Since 1800 s, the berries of this plant have been known for their medicinal importance to treat patients with prostatic enlargement (223). Some mild side effects have been associated with $S$. repens such as headache, abdominal pain, and nausea (35). Additionally, saw palmetto was found to be hepatotoxic and harboring severe side effects including acute liver damage (41), cholestatic hepatitis (113) and acute pancreatitis $(16,36,224)$. According to Hamid, Rojter \& Vierling (39), prostata is a common preparation of saw palmetto that has been implicated in protracted cholestatic hepatitis. The mechanism by which saw palmetto induces its effect is not fully understood (36), however; some suggestions are pointing to the estrogenic and antiandrogenic effects (36). Pyrrolizidine alkaloids-containing herbs have been used as herbal remedies to treat many illnesses. One of well-known pyrrolizidine alkaloids-containing agent is Symphytum officinale that is commonly known as comfrey $(8,54)$. Leaves and roots of comfrey have been used as a remedy externally (bone fractures, reduce joint inflammation, wound healing) and internally (gastroduodenal ulcers and gastritis) $(8,46)$. However, pyrrolizidine alkaloids, which were first recognized as toxins in 1920 (225), are major health hazards (8). Comfrey has been reported to be hepatotoxic and cause hepatic VOD (8). VOD of the liver has been linked with ingestion of contaminated plants with pyrrolizidine alkaloids (54). Moreover, some other factors that contribute to VOD of the liver include chemotherapy, irradiation, tyrosinaemia and systemic lupus erythromatosus (54). The mechanism of action of comfrey has not been established due to the involvement of multiple constituents (226). Hepatotoxicity of comfrey could be linked to several factors including susceptibility of host, route of exposure as well as ingested dose $(43,51)$. Though, comfrey-induce injury could be due to destruction of veins that cause cirrhosis and finally liver failure (226) or hepatic congestion due to fibrous obliteration of small hepatic veins (54). Another serious druginduced hepatotoxicity is constituted by Teucrium genus, which involves over 300 species worldwide (60). Two important species are Teucrium chamaedrys (wall germander) and Teucrium polium $(60,17)$ that have been used for more than 2000 years as a treatment against overweight and obesity (17). Although, germander has been considered to be risk free, many cases of its hepatotoxic effect have been reported indeed $(5,17,60,65)$. Teucrium poliuminduced hepatotoxicity has been observed in several cases as well $(61,64,227-230)$. The mechanism of hepatotoxic action of germander is not well known. However, some studies may contribute to the hepatotoxic potential pointing to the furano neoclerodane diterpenoids constituent, found mainly in teucrin A $(61,231)$. Accordingly, two cases reported that dual mechanisms- direct toxicity and secondary immune reactions- can mediate germander hepatotoxicity $(60,232)$. Moreover, an immunoallergic mechanism may be involved and accounts for germander toxicity (17). Kava, obtained from Piper methysticum roots, has been traditionally used for ceremonial and medicinal purposes and as remedy for insomnia and anxiety (68). The active constituent of kava is kavapyrones, which are responsible for the pharmacological properties $(68,70,73)$. However, the first case report described the 
hepatotoxic effect of kava was in 1998 (233). Consecutively, several case reports of association of kava consumption with hepatic injury have been reported $(70,234)$. The spectrum of liver injury induced by kava ingestion includes hepatitis, cirrhosis, and liver failure (68). Yet, the mechanism involved in kava hepatotoxicity has not been identified, however, immunoallergic reaction and metabolic idiosyncratic reaction have been proposed $(70,235)$. Various risk factors may contribute to liver toxicity of kava including genetic polymorphism of cytochrome P450 enzyme, co-medication, and existing liver injury (236). Moreover, Chelidonium majus or greater celandine is a well-known herbal remedy for the treatment of gastrointestinal tract diseases (81). However, Greater Celandine showed to cause several hepatotoxic events. The toxic constituent of greater celandine responsible of hepatotoxicity is not yet known (136). Moreover, the exact mechanism of liver toxicity is unknown. Some of suggested mechanisms include an autoimmune mechanism due to the presence of eosinophilic infiltrates and autoantibodies in some cases. Another possible mechanism is idiosyncratic mechanism (13). Another dangerous herbaceous botanical is Atractylis gummifera, which has been commonly used in Mediterranean countries as antipyretic, purgative and diuretic $(30,100)$. This plant is a life-threatening poisoning where all plant parts are toxic (240). Moreover, A. gummifera has been associated with several cases of hepatotoxicity including hepato-renal injury (89), hepatic necrosis (91) and death $(91,95)$. Moreover, two main constituents are responsible for A. gummifera toxicity, which are atractylosides and gummiferin. The proposed mechanism of A. gummifera-induce hepatotoxicity could be due to mitochondrial toxicity via inhibition of oxidative phosphorylation and induction of oxidative stress $(95,100)$. Callilepsis laureola or Impila is another dangerous herb (97). It is a multifunctional remedy that used for treating stomach discomfort, cough, worm infection and impotence $(97,98)$. However, Impila is a sever poison and patients poisoned by it show sever hypoglycemia (102). Moreover, several reports reported cases of hepatotoxicity and renal toxicity including acute renal failure (241), hepatocellular necrosis (98) and hepatic and renal dysfunction along with hypoglycemia (102) as well as death (99). As in Atractylis gummifera, Callilepsis laureola contains toxic atractylosides, which is responsible for fulminant hepatitis and renal tubular necrosis injury (101). Additionally, atractylosides act by inhibiting the oxidative phosphorylation (242). Chinese Herbal Medicine has been known for more than 4000 years and used as therapy for several illnesses (103). However, various hepatotoxic effects after consumption of Chinese herbal preparations have been reported (94). Jin $\mathrm{Bu}$ Huang is a common Chinese herb that used as analgesic, sedative and sleeping aid (30). However, JBH has been associated with acute and chronic hepatitis $(105,107)$. Accordingly, the active component of JHB is the extract from Lypocodium serratum plant $(94,106)$. The potential mechanism of liver damage induced by Jin Bu Huang is unknown (243). Additionally, Ma Huang derived from Ephedra sinica has been commonly used in China as a slimming aid as well as a therapy for cough and bronchitis $(109,110,111)$. Several cases of Ma Huang hepatotoxicity have been reported $(109,110,115,116)$. The major constituent in Ma Huang that is responsible for toxic effects is Ephedrine (110). The hepatotoxic action of Ma Huang could be immune-mediated $(106,130,244)$. Another commonly used herb in China is ShouWu-Pian, which is derived from Polygonum multiflorum $(113,119)$. It is a mixture of Chinese herbs that has been used as a treatment for several illnesses including backache, constipation, dizziness, greying of hair, spermatorrhea, lumbago and treating symptoms of chronic prostatitis $(120,121,122)$. Yet, Shou-Wu-Pian found to cause acute hepatitis in adults and children $(119,120,125)$. This hepatotoxic effect of The Shou-Wu-Pian is ascribed to toxic constituent, anthraquinone (120). Furthermore, the potential hepatotoxic mechanism of Shou-WuPian is not fully described (125). Another Chinese herb is Dictamnus dasycarpus, which has been used for treating skin diseases (127). Few reports reported hepatotoxic events and death associated with consumption $D$. dasycarpus with other herbal preparation $(128,129,130,131)$. Additionally, Kampo medicine including DaiSaiko-to and Syo-saiko-to consists of mixture of herbs that has been used as a remedy of several illnesses like dyspepsia and pyretic diseases $(10,133)$. However, these herbal medicine have been linked with some cases of hepatotoxicity $(132,134)$. Accordingly, the toxic agents responsible for hepatotoxicity of these kampo herbs are glycyrrhiza, and scutellaria constituents $(132,133)$. Moreover, the mechanism by which these herbs induce hepatotoxicity is not fully understood (132). Another popular plant is Kombusha mushroom, which is not a true mushroom as it involves symbiotic yeast and 
bacteria grouped together and surrounded by a permeable membrane (132). It is commonly used as health tonic to improve health (106). Nevertheless, several cases of toxicity have been reported due to intake of Kombusha tea (138). The potential mechanism involved in Kombusha toxicity could be attributed to usnic acid found in Kombusha. Thus, usnic acid can cause hepatic damage due to uncoupling of oxidative phosphorylation of mitochondria and induction of oxidative stress $(106,113)$. Moreover, toxic action of Kombusha could be due to contamination if it is prepared in ceramic of lead containers $(139,140)$. Cassia angustifolia or senna is a another common herb that has been used for its laxative properties $(141,142)$. The leaves and fruits of senna have been associated with toxic hepatitis (143), acute hepatic failure (141), portal vein thrombosis (142) and subacute cholestatic hepatitis (144). The toxic constituent of senna is sennosides and anthraquinone glycosides $(93,94,100,143)$. Moreover, the hepatotoxic effect of $C$. angustifolia is uncommon and could be due to exposure of liver to massive amounts of toxic metabolites of anthraquinone glycosides $(141,142)$. Moreover, Pennyroyal oil obtained from Mentha pulegium or Hedeoma Pulegoides has been used as abortifacient and pesticide against insects and fleas $(145,146,149)$. However, several cases of pennyroyal oil intoxication have been reported (150) as well as cases of fulminant hepatic necrosis (149). The main constituent responsible of pennyroyal hepatotoxicity is pulegone and some other monoterpenes (149). The possible mechanism of pennyroyal causing hepatotoxicity involves the oxidization of menthofuran, which is pulegone metabolite, by cytochrome P450s $(245,246)$. Moreover, the pulegone cause depletion of hepatic glutathione through formation of electrophilic metabolites, which increases the concentration of menthofuran leading to hepatotoxicity $(149,247)$. Another common oil is Margosa or Neem oil extracted from Azadirachta indica A. Juss (Neem tree), which has been widely used to obtain good health and it is usually given to infants and children (151). However, several cases of hepatotoxicity, neurodeficit and renal tubular acidosis associated with Margosa poisoning have been reported $(151,152,154,155)$. The toxic effect of Margosa oil has been attributed to the bitters constituents of this oil including nimbin, nimbidin, nimbinin and nimbidol (152). Accordingly, the potential mechanism of toxicity of Margosa oil could be due to toxic effect on mitochondria (155). One of most important herb involved in herb-drug interaction is St. John's Wort (SJW) extracted from Hypericum perforatum (165). More than 2000 years ago, SJW has been used as a remedy for several conditions but mainly as an antidepressant $(156,157,158)$. It has been implicated in interaction with various pharmaceutical $(111,158,159,160)$. SJW-drug interaction can lead to serious consequences for example causing intermenstrual bleeding when taking with oral contraceptives, increasing total cholesterol levels and LDL cholesterol levels when taking with rosuvartatin, reducing plasma cyclosporine concentrations, acute liver transplant rejection when taking with cyclosporine $(161,162,163,248)$. The responsible constituent of causing SJW-drug interaction is known to be hyperforin $(156,157)$. Hyperforin causes induction cytochrome $\mathrm{P} 450$ enzymes level, particularly CYP3A4 and induction of Pglycoprotein activity (249). Another hepatotoxic plant is Valeriana officinalis or valerian that is available as a mixture with other herbs as over the counter medicine for the treatment of anxiety and insomnia (167). However, valerian has been associated with both cytotoxicity (250) and hepatotoxicity (168) with only few cases have been reported (251). Additionally, valerian has the ability to interact with other drugs and herbs (169). The main constituents of valerian are valepotriates (iridoids) and volatile oil with some other alkaloids (252). Moreover, alkylating agents found to be responsible for the toxic effects of valerian (168). The exact mechanism of valerian causing hepatotoxicity is unknown (166). However, one of suspected mechanism of toxicity involves hypersensitivity reactions (10). Furthermore, Viscum album or European mistletoe is a semi-parasitic woody perennial plant that is indigenous to Europe and Asia (170). The leaves, berries and branches of mistletoe are used for treatment of different conditions like hypertension, asthma, infertility, insomnia, epilepsy, cancer and urinary disorders $(30,171)$. However, mistletoe found to contain toxic constituents in all plant parts like lectins (170). Some of side effects associated with this botanical involve fever, chills and headaches (170). Moreover, mistletoe hepatotoxicity is debated and only few cases have been reported $(93,100,168)$. The possible mechanism of mistletoe-induced hepatotoxicity is unknown and no suggested mechanisms were found. Another commonly used herb is Scutelloria baicalensis or skullcap, which has been used as an anti-inflammatory, antispasmodic and sedative agent and for treating arthritis, jaundice, cancer, hepatitis, epilepsy and 
nervous tension $(82,111,173,175,176)$. However, several reports reported cases of skullcap inducing hepatotoxic injury either alone or in compensation with other herbs such as mistletoe $(172,173,176)$. Accordingly, skullcap contains terpenoid compounds, which are hydrocarbons that consists of isoprene unites. They are widely distributed in nature, particularly in plant kingdom as a constituent of essential oils in oxygenated derivatives form $(10,113)$. The presence of terpenoid compounds in skullcap is a potential mechanism by which skullcap could cause hepatotoxic injury as well as venoocclusive disease (106). Moreover, NONI juice from Morinda citrifolia fruit has been used for centuries as a Polynesian herbal medicine to maintain wellness $(180,183)$. However, the consumption of noni juice has been associated with sever cases of hepatotoxicity including acute hepatitis $(178,180,183)$, fulminant hepatitis $(182)$ and hyperkalemia in a patient with renal failure (253). The main toxic constituents of noni juice are anthraquinones involving rubiadin, rubiadin1-methyl ether, anthraquinone glycoside, moridone and nordamnacanthal that are known to cause hepatotoxic events $(180,182)$. The exact mechanism of noni juice-inducing hepatotoxicity is unknown; however, potential hepatotoxicity could be attributed to the presence of anthraquinones (180). Rhein- a product of anthraquinone- cause intracellular glutathione depletion, mitochondrial membrane potential reduction, lipid peroxidation initiation leading to death of cell by production of oxygen derived free radicals through redox cycling (254). Amatoxincontaining mushrooms like Amanita phalloides can cause sever poisoning leading to death (94). Several cases of Amanita phalloides poisoning have been reported $(185,186,188)$. Thus, the toxicity is due to two toxins, which are phalloidin and $\alpha$ - amanitin. phalloidin is not sever toxin as it disrupts cellular membrane by irreversible polymerization of both G- and F-actin. Thus, phalloidin is only responsible for gastrointestinal symptoms $(184,187)$. On the other hand, amanitins ( $\alpha$-amanitin) is the one responsible for sever toxicity of Amanita phalloides. It is absorbed in intestine affect liver (184). Amanitins causes toxicity by inhibiting the activity of RNA polymerase II leading to interruption of protein synthesis and causing cell death $(184,187)$. Additionally, Sassafras oil extracted from sassafras albidum tree has been used as a remedy for several illnesses including urinary tract disorder and kidney diseases (145). However, sassafras showed to contain toxic safrole as its major constituent (192). Due to high concentration of safrole presented in sassafras, FDA banned intake of sassafras (145). Another hepatotoxic herb is Echinacea that belongs to North America and has been used by Plains Indians for treating respiratory infections and fever $(194,195)$. Three species have been medicinally used including $E$. angustifolia, E. pallida and E. purpurea. However, the potential hepatotoxicity of Echinacea is linked with prolong intake of herb for more than 8 weeks as well as consumption of other hepatotoxic medications $(193,194)$. Moreover, presence of PA could be associated with liver toxicity but it was reported that PA of Echinacea is lacking 1,2 saturated necrine ring associated with toxic effect of PA $(193,194)$. Additionally, the exact mechanism of Echinacea hepatotoxicity is not yet determined (193).

We reviewed and analyzed some of herbal preparations and their hepatotoxic effects; however, our review is limited due to some incomplete information regarding dosage of drug, duration of use, ingredients of plant and previous medical history of patients. Additionally, articles were restricted to English only and human studies/cases that occurred during 1900 to 2013 periods.

In conclusion, adverse serious events of hepatotoxicity were reported and evidence provides that herbs are not hepatotoxicity free. Botanicals are self-prescribed and widely available, which make them difficult to control. In order to minimize the harm of herbal products, patients should provide accurate information about their health and susceptibility to liver disease as well as complete details of their usage. Additionally, they should search for herbs that meet good therapy standards and follow recommended dose provided by their physicians or pharmacists. Moreover, healthcare providers and physicians must report about all events associated with herbal use and advise about adverse reactions to such herbs worldwide in a common and accessible web-based database. Extensive education of practitioners, pharmacists and physicians about natural medicines is probably needed and this review intended to pharmacological scientists would be the basis for future seminars and workshops. Further research and studies are required in order to identify toxic constituents in each herbal preparation as well as possible mechanism(s)of hepatotoxicity. We would also suggest that (1) more scientific studies on immortalized normal hepatocytes are needed to identify toxic compounds and understand the 
exact mechanism of hepatotoxicity; (2) a database with adverse effects of herbal products should be open and web details should be made accessible to general practitioners; and (3) seminars and workshops on herbal therapy should probably have experts in liver metabolism on board to explain hepatotoxic effects of alternative medicine.

\section{ACKNOWLEDGEMENT}

The authors are very grateful to the Saudi Cultural Bureau, Ottawa, ON, Canada, for the financial support of Ms. Reem Abdualmjid, MSc Graduate Student in the program Laboratory Medicine and Pathology at the University of Alberta, Edmonton, $\mathrm{AB}$, Canada.

\section{REFERENCES}

1. Schuppan D, Jia JD, Brinkhaus B, Hahn EG. Herbal products for liver diseases: A therapeutic challenge for the new millennium. Hepatolo, 2003; 30(4): 1099-1104.

2. Moore J, Phipps K, Marcer D, Lewith G. Why do people seek treatment by alternative medicine? Br. Med. J, 1985; 290(6461): 28.

3. Navarro VJ. Herbal and Dietary Supplement Hepatotoxicity. Semin Liver Dis, 2009; 29(4): 373-382.

4. Shad JA, Chinn CG, Brann OS. Acute Hepatitis After Ingestion of Herbs. South Med J, 1999; 92(11): 1095.

5. Laliberté L, Villeneuve JP. Hepatitis after the use of germander, a herbal remedy. CMAJ, 1996; 154(11): 1689-1692.

6. Jaeschke H, Gores GJ, Cederbaum AI, Hinson JA, Pessayre D, Lemasters JJ. Mechanisms of hepatotoxicity. Toxicol Sci, 2002; 65(2): 166-176.

7. Willett KL, Roth RA, Walker L. Workshop Overview: Hepatotoxicity Assessment for Botanical Dietary Supplements. Toxicol Sci, 2004; 79(1): 4-9.

8. Stickel F, Seitz HK. The efficacy and safety of comfrey. Pub Health Nutr, 2000; 3(4A): 501-508.

9. Bhawna S, Kumar SU. Hepatoprotective activity of some indigenous plants. Int. J. PharmTech Res, 2010; 2(1): 568-572.

10. Pittler MH, Ernst E. Systematic review: hepatotoxic events associated with herbal medicinal products. Aliment Pharmacol Ther, 2003; 18(5): 451-471.

11. Huxtable RJ. The myth of beneficial nature: the risk of herbal preparations. Ann Intern Med, 1992; 117(2): 165-166.

12. Kaplowitz N. Idiosyncratic drug hepatotoxicity. Nat Rev Drug Discov, 2005;4(6): 489-499.

13. Stedman C. Herbal hepatotoxicity. Semin Liver Dis, 2002; 22(2): 195-206.
14. Whiting PW, Clouston A, Kerlin P. Black cohosh and other herbal remedies associated with acute hepatitis. MJA, 2002; 177(8): 440-443.

15. Sheikh NM, Philen RM, Love LA. Chaparralassociated hepatotoxicity. Arch Intern Med, 1997;157(8): 913-919.

16. Jibrin I, Erinle A, Saidi A, Aliyu ZY. Saw palmetto-induced pancreatitis. South Med J, 2006; 99(6): 611-612.

17. Larrey D, Vial T, Pauwels A, Castot A, Biour M, Michel $\mathrm{H}$, et al. Hepatitis after Germander (Teucrium chamaedrys) Administration: Another Instance of Herbal Medicine Hepatotoxicity. Ann Intern Med, 1992; 117(2): 129-132.

18. Fu PP, Xia Q, Guo L, Yu H, Chan PC. Toxicity of Kava Kava. J Environ Sci Health C Environ Carcinog Ecotoxicol Rev, 2008; 26(1): 89-112.

19. Compton JA, Culham A, Jury SL. Reclassification of Actaea to Include Cimicifuga and Souliea (Ranunculaceae): Phylogeny Inferred from Morphology, nrDNA ITS, and cpDNA trnL-F Sequence Variation. Taxon, 1998; 47(3): 593-634.

20. WHO Monographs on Selected Medicinal Plants. Volume 2 [monograph on the Internet]. World Health Organization; 2002. [cited June 5, 2012]. Available from: eBook Collection (EBSCOhost): http://ehis.ebscohost.com.login.ezproxy.library.ual berta.ca/eds/ebookviewer/ebook/nlebk_91392_AN ?sid=5a85e2ed-4a9d-4131-90019ca753b794b3@sessionmgr14\&vid=11

21. Foster S. Black Cohosh: Cimicifuga racemosa; A Literature Review. Herbalgram, 1999; (45): 35.

22. Blumenthal M, Busse W, Goldberg A, et al. The Complete German Commission E Monographs: Therapeutic Guide to Herbal Medicines. Boston: Integrative Medicine Communications; 1998:90.

23. Chow EC, Teo M, Ring JA, Chen JW. Liver failure associated with the use of black cohosh for menopausal symptoms. Med J Aust, 2008; 188(7): 420-422.

24. Levitsky J, Alli TA, Wisecarver J, Sorrell MF. Fulminant liver failure associated with the use of black cohosh. Dig Dis Sci, 2005; 50(3): 538-539.

25. Cohen SM, O'Connor AM, Hart J, Merel NH, Te HS. Autoimmune hepatitis associated with the use of black cohosh: a case study. Menopause (10723714), 2004; 11(5): 575-577.

26. Stuart, Will. Black cohosh (Actaea racemosa) on the BRP. Digital Image. Flickr.com. 13 July 2007. Web. 13 June 2012. $<$ http://www.flickr.com/photos/willstuart/8387303 $93 />$

27. Cupp MJ. Toxicology and Clinical Pharmacology of Herbal Products [monograph on the Internet]. Humana Press, 2000. [cited June 5, 2012]. Available from: eBook Collection (EBSCOhost).

28. Grant KL, Boyer LV, Erdman BE. Chaparralinduced hepatotoxicity. IntegrMed, 1998; 1(2): 8387.

29. Centers for Disease Control and Prevention. Chaparral-induced toxic hepatitis-California and Texas. MMWR Morb Mortal Wkiy Rep, 
1992;41:812-1.

30. Schiano TD. Liver Injury from Herbs and Other Botanicals. Clin Liver Dis, 1998; 2(3): 607-630.

31. Kauma H, Koskela R, Mäkisalo H, AutioHarmainen H, Lehtola J, Höckerstedt K. Toxic acute hepatitis and hepatic fibrosis after consumption of chaparral tablets. Scand J Gaslroenterol, 2004; 39(11): 1168-1171.

32. Katz M, Saibil F. Herbal hepatitis: subacute hepatic necrosis secondary to chaparral leaf. J Clin Gastroenterol, 1990; 12(2): 203-206.

33. Hunt, Eric. Larrea tridentata. Digital Image. Flickr.com. 21 March 2010. Web. 13 June 2012. < http://www.flickr.com/photos/ericinsf/4462688008 s>

34. Tacklind J, MacDonald R, Rutks I, Stanke JU, Wilt TJ. Serenoa repens for benign prostatic hyperplasia. Cochrane Database Syst Rev, 2009; (2).

35. Agbabiaka TB, Pittler MH, Wider B, Ernst E. Serenoa repens (Saw Palmetto). Drug Saf, 2009; 32(8): 637-647.

36. Bruminhent J, Carrera P, Li Z, Amankona R, Roberts IM. Acute pancreatitis with saw palmetto use: a case report. J Med Case Rep, 2011; 5:414.

37. Coleman CI, Hebert JH, Reddy P. The effect of phytosterols on quality of life in the treatment of benign prostatic hyperplasia. Pharmacotherapy, 2002; 22(11): 1426-1432.

38. Champault G, Patel JC, Bonnard AM. A doubleblind trial of an extract of the plant Serenoa repens in benign prostatic hyperplasia. Br. J. clin. Pharmacol, 1984; 18(3): 461-462.

39. Hamid S, Rojter S, Vierling J. Protracted cholestatic hepatitis after the use of prostata. Ann Intern Med, 1997; 127(2): 169-170.

40. Dankoff JS. Near fatal liver dysfunction secondary to administration of flutamide for prostate cancer. J Urol, 1992; 148(6): 1914.

41. Lapi F, Gallo E, Giocaliere E, Vietri M, Baronti R, Vannacci A, et al. Acute liver damage due to Serenoa repens: a case report. Br. J. clin. Pharmacol, 2010; 69(5): 558-560.

42. Martin, Tim. Saw Palmetto - Serenoa repens. Digital image. Flicker.com. 6 October 2011. Web. $13 \quad$ June 2012. <http://www.flickr.com/photos/52014195@N08/6 318659851/>

43. Mei N, Guo L, Fu PP, Fuscoe JC, Luan Y, Chen T. Metabolism, Genotoxicity, annd Carcinogenicity of Comfrey. J. Toxicol. Environ. Health: Part B, 2010; 13(7/8): 509-526.

44. Betz JM, Eppley RM, Taylor WC, Andrzejewski D. Determination of pyrrolizidine alkaloids in commercial comfrey products (Symphytum sp.). J Pharm Sci, 1994; 83(5): 649-653.

45. Winship KA. Toxicity Of Comfrey. Adverse Drug React. Toxicol. Rev, 1991; 10(1): 47-59.

46. Rode D. Comfrey toxicity revisited. Trends Pharmacol. Sci, 2002; 23(11): 497-499.

47. Roeder E. Medicinal plants in Europe containing pyrrolizidine alkaloids. Die Pharmazie, 1995;
50(2): 83-98.

48. Essell JH, Thompson JM, Harman GS, Halvorson RD, Snyder MJ, Rubinsak JR, et al. Marked increase in veno-occlusive disease of the liver associated with methotrexate use for graft-versushost disease prophylaxis in patients receiving busulfan/cyclophosphamide. Blood, 1992; 79(10): 2784-2788.

49. Couet CE, Crews C, Hanley AB. Analysis, separation, and bioassay of pyrrolizidine alkaloids from comfrey (Symphytum officinale). Nat Toxins, 1996; 4(4): 163-167.

50. Ridker PM, Ohkuma S, McDermott WV, Trey C, Huxtable RJ. Hepatic venocclusive disease associated with the consumption of pyrrolizidinecontaining dietary supplements. Gastroenterology, 1985; 88(4): 1050-1054.

51. Ridker PM, McDermott WV. Comfrey herb tea and hepatic veno-occlusive disease. Lancet, 1989; 1(8639): 657-658.

52. DeLeve LD, Shulman HM, McDonald GB. Toxic injury to hepatic sinusoids: sinusoidal obstruction syndrome (veno-occlusive disease). Semin Liver Dis, 2002; 22(1): 27-42.

53. Sperl W, Stuppner H, Gassner I, Judmaier W, Dietze O, Vogel W. Reversible hepatic venoocclusive disease in an infant after consumption of pyrrolizidine-containing herbal tea. Eur J Pediatr, 1995; 154(2): 112-116.

54. Consolato S, Bernhard B, Otwin L, Walter J. H. Fatal Course of Veno-occlusive Disease of the Liver (Endophlebitis Hepatica obliterans) in a Preterm Infant. Pathol Res Pract. 1999; 195(12): 847-851.

55. Gyorik S, Stricker H. Severe pulmonary hypertension possibly due to pyrrolizidine alkaloids in polyphytotherapy. Swiss Med. Weekly, 2009; 139(13-14): 210-211.

56. Yeong ML, Swinburn B, Kennedy M, Nicholson G. Hepatic veno-occlusive disease associated with comfrey ingestion. J. Gastroenterol. Hepatolo, 1990; 5(2): 211-214.

57. Bach N, Thung SN, Schaffner F. Comfrey herb tea-induced hepatic venoocclusive disease. Am. J. Med, 1989; 87(6): 97-99.

58. Weston CF, Cooper BT, Davies JD, Levine DF. Veno-occlusive disease of the liver secondary to ingestion of comfrey. Br. Med. J. (Clin. Res. Ed.), 1987; 295(6591): 183.

59. Marks, Rachel. Comfy comfrey. Digital image. Flickr.com. 23 December 2007. Web. 13 June 2012.

$<$ http://www.flickr.com/photos/chooknage/213654 7967/>

60. Gori L, Galluzzi P, Mascherini V, Gallo E, Lapi F, Firenzuoli F, et al. Two Contemporary Cases of Hepatitis Associated with Teucrium Chamaedrys L. Decoction Use. Case Reports and Review of Literature. Basic Clin. Pharmacol. Toxicol, 2011; 109(6): 521-526.

61. Savvidou S, Goulis J, Giavazis I, Patsiaoura K, Hytiroglou P, Arvanitakis C. Herb-induced 
hepatitis by Teucrium polium L.: report of two cases and review of the literature. Eur $\mathrm{J}$ Gastroenterol Hepatol, 2007; 19(6): 507-511.

62. Zhou SF, Xue CC, Yu XQ, Wang G. Metabolic activation of herbal and dietary constituents and its clinical and toxicological implications: an update. Curr Drug Metab, 2007;8:526-53.

63. European Commission Health \& Consumer Protection Directorate-General. Opinion of the Scientific Committee on Food on Teucrin A, major component of hydroalcoholic extracts of Teucrium chamaedrys (wild Germander). Expressed on 5 March 2003.

64. Mazokopakis E, Lazaridou S, Tzardi M, Mixaki J, Diamantis I, Ganotakis E. Acute cholestatic hepatitis caused by Teucrium polium L. Phytomedicine, 2004; 11: 83-84.

65. Lekehal M, Pessayre D, Lereau JM, Moulis C, Fouraste I, Fau D. Hepatotoxicity of the herbal medicine Germander: metabolic activation of its furano diterpenoids by cytochrome P450 3A depletes cytoskeleton associated protein thiols and forms plasma membrane blebs in rat hepatocytes. Hepatol, 1996; 24: 212-8.

66. Mostefa-Kara N, Pauwels A, Pines E, Biour M, Levy VG. Fatal hepatitis after herbal tea. Lancet, 1992; 340(8820): 674.

67. Greenwood, Peter. Teucrium chamaedrys L. - Wall Germander. Digital image. Flickr.com. 30 July 2010. Web. 14 June 2012. <http://www.flickr.com/photos/21657471@N04/4 937452291/>

68. Humberston C, Akhtar J, Krenzelok E. Acute Hepatitis Induced by Kava Kava. J. Toxicol Clin Toxicol, 2003; 41(2): 109.

69. Singh YH. kava - an overview. J Ethnopharmacol, 1992; 37(1): 13-45.

70. Stickel F, Baumüller HM, Seitz K, Vasilakis D, Seitz G, Seitz HK, Schuppan D. Hepatitis induced by Kava (Piper methysticum rhizoma). J Hepatol, 2003; 39(1): 62-67.

71. Denham A, McIntyre M, Whitehouse J. Kava - the unfolding story: report on a work-in-progress. J Altern Complement Med, 2002; 8(3): 237-263.

72. Steiner GG. The correlation between cancer incidence and kava consumption. Hawaii Med J, 2000; 59(11): 420-422.

73. Whitton PA, Lau A, Sallsbury A, Whitehouse J, Evans CS. Kava lactones and the kava-kava controversy. Phytochemistry, 2003; 64(3): 673679.

74. Sarris J, LaPorte E, Schweitzer I. Kava: a comprehensive review of efficacy, safety, and psychopharmacology. Aust N Z J Psychiatry, 2011; 45(1): 27-35.

75. Siméoni P, Lebot V. Identification of factors determining kavalactone content and chemotype in Kava (Piper methysticum Forst. f.). Biochem. Syst. Ecol, 2002; 30(5): 413.

76. Escher M, Desmeules J, Giostra E, Mentha G. Drug points: Hepatitis associated with Kava, a herbal remedy for anxiety. Br. Med. J, 2001;
321(7279): 139.

77. Sass M, Schnabel S, Kroger J, Liebe S, Schareck WD. Acute liver failure from kavakava-a rare indication for liver transplantation. Z Gastroenterol, 2001; 39: 491.

78. Kraft MT, Spahn TW, Menzel J, Senninger N, Dietl $\mathrm{KH}$, Herbst $\mathrm{H}$ et al. Fulminant liver failure after administration of the herbal antidepressant Kava-Kava. Dtsch Med Wochensch, 2001; 126(36): 970-972.

79. Russmann S, Lauterburg BH, Helbling A. Kava hepatotoxicity. Ann Inter Med, 2001; 135(1): 6869.

80. Manners, Malcolm. Kava. Digital image. Flickr.com. 23 June 2006. 14 June 2012. http://www.flickr.com/photos/mmmavocado/4253 769423/

81. Moro PA, Cassetti F, Giugliano G, Falce MT, Mazzanti G, Menniti-Ippolito F, et al. Hepatitis from Greater celandine (Chelidonium majus L.): review of literature and report of a new case. J Ethnopharmacol, 2009; 124(2): 328-332.

82. Gilca M, Gaman L, Panait E, Stoian I, Atanasiu V. Chelidonium majus-an Integrative Review: Traditional Knowledge versus Modern Findings. Forsch Komplementmed, 2010; 17(5): 241.

83. Stickel F, Patsenker E, Schuppan D. Herbal hepatotoxicity. Journal of hepatology, 2005; 43(5): 901.

84. Stickel F, Poschl G, Seitz H, Waldherr R, Hahn E, Schuppan D. Acute hepatitis induced by Greater Celandine (Chelidonium majus). Scand J Gastroenterol, 2003; 38(5): 565-568.

85. Teschke R, Glass X, Schulze J, Eickhoff A. Suspected Greater Celandine hepatotoxicity: liverspecific causality evaluation of published case reports from Europe. Eur J Gastroenterol Hepatol, 2012, 24(3): 270-280.

86. Benninger J, Schneider HT, Schuppan D, Kirchner T, Hahn EG. Acute hepatitis induced by greater celandine (Chelidonium majus). Gastroenterology, 1999; 117(5): 1234-1237.

87. Bark KM, Heo EP, Han KD, Kim MB, Lee ST, Gil EM, Kim TH: Evaluation of the phototoxic potential of plants used in oriental medicine. J Ethnopharmacol, 2010; 127(1): 11-18.

88. Kaminsky V, Lootsik M, Stoika R: Correlation of the cytotoxic activity of four different alkaloids, from Chelidonium majus (greater celandine), with their DNA intercalating properties and ability to induce breaks in the DNA of NK/Ly murine lymphoma cells. Cent Eur J Biol, 2006; 1(1): 215.

89. Bouziri A, Hamdi A, Menif K, Ben Jaballah N. Hepatorenal injury induced by cutaneous application of Atractylis gummifera L. Clinical Toxicology, 2010; 48(7): 752-754.

90. Vallejo JR, Peral D, Gemio P, Carrasco MC, Heinrich M \& Pardo-de-Santayana M. Atractylis gummifera and Centaurea ornata in the Province of Badajoz (Extremadura, Spain)Ethnopharmacological importance and 
toxicological risk. J Ethnopharmacol, 2009; 126 (2): 366-70.

91. Daniele C, Dahamna S, Firuzi O, Sekfali N, Saso L, Mazzanti G. Atractylis gummifera L. poisoning: an ethnopharmacological review. J Ethnopharmacol, 2005; 97(2): 175-181.

92. Larrey D, Pageaux GP. Hepatotoxicity of herbal remedies and mushrooms. Semin Liver Dis, 1995; 15:183.

93. Larrey D. Hepatotoxicity of herbal remedies. J Hepatol, 1997; 26:47.

94. Stickel F, Egerer G, Seitz HK. Hepatotoxicity of botanicals. Public Health Nutr, 2000; 3113-124.

95. Georgiou M, Sianidou L, Hatzis T, Papadatos J, Koutselinis A. Hepatotoxicity due to Atractylis gummifera-L. J Toxicol Clin Toxicol, 1988; 26(7): 487-493.

96. Popat A, Shear NH, Malkiewicz I, Stewart MJ, Steenkamp V, Thomson S, Neuman MG The toxicity of Callilepis laureola, a South African traditional herbal medicine. Clin Biochem, 2001; 34: 229-236.

97. Bye SN, Dutton MF. The inappropriate use of traditional medicines in South Africa. J Ethnopharmacol, 1991; 34: 253-259.

98. Steenkamp V, Stewart MJ, Zuckerman M. Detection of poisoning by Impila (Callilepis laureola) in a mother and child. Hum Exp Toxicol, 1999; 18(10): 594-597.

99. Bryant AT. Zulu medicine and medicine-men. Ann Natal Museum, 1909; 2:1-103

100.Felix S, Eleonora P, Detlef S. Review: Herbal hepatotoxicity. J Hepatol, 2010; 43(5): 901-910

101.Mokhobo KP. Herb use and necro-degenerative hepatitis. S Afr Med J, 1976; 50: 1096-1099.

102. Watson A, Coovadia H, Bhoola K. The clinical syndrome of Impila (Callilepis laureola) poisoning in children. S Afr Med J, 1979; 55(8): 290-292.

103. Vanherweghem, Jean-Louis, C. Tielemans, D. Abramowicz, M. Depierreux, R. Vanhaelen-Fastre, M. Vanhaelen, M. Dratwa et al. Rapidly progressive interstitial renal fibrosis in young women: association with slimming regimen including Chinese herbs. Lancet, 1993; 341(8842): 387-391.

104.Deng S, May B, Zhang A, Lu C, Xue C. Topical herbal medicine combined with pharmacotherapy for psoriasis: a systematic review and metaanalysis. Arch Dermatol Res, 2013; 305(3): 179189.

105. Woolf GM, Rojter SE, Villamil FG, Vierling JM, Katkov W, Stermitz FR, Beck JJ. Jin Bu Huan toxicity in adults - Los Angeles. Morb Mortal Wkly Rep, 1993; 42: 920-922.

106.Frazier TH, Krueger KJ. Hepatotoxic herbs: will injury mechanisms guide treatment strategies? Curr Gastroenterol Rep, 2009; 11(4): 317-324.

107.Picciotto A, Campo N, Brizzolara R, Giusto R, Guido G, Sinelli N, Lapertosa G and Celle G. Chronic hepatitis induced by Jin $\mathrm{Bu}$ Huan. J Hepatol, 1998; 28(1): 165-167.
108. Woolf GM, Petrovic LM, Rojter SE, Wainwright S, Villamil, FG, Katkov WN et al. Acute hepatitis associated with the Chinese herbal product Jin $\mathrm{Bu}$ Huan. Ann Intern Med, 1994; 121: 729-35.

109.koulidis F, Alexander GJ, Davies SE. Ma huang associated acute liver failure requiring liver transplantation. Eur J Gastroenterol Hepatol, 2005; 17(5): 581-584.

110.Nadir A, Agrawal S, King PD, Marshall JB. Acute hepatitis associated with the use of a Chinese herbal product, ma-huang. Am J Gastroenterol, 1996; 91(7): 1436-1438.

111.Seeff LB: Herbal hepatotoxicity. Clin Liver Dis, 2007: 11(3): 577-596.

112. Shekelle PG, Mary LH, Sally CM, Margaret M, Walter AM, Marika JS et al. Efficacy and safety of ephedra and ephedrine for weight loss and athletic performance. JAMA, 2003; 289(12): 1537-1545.

113. Chitturi S, Farrell GC. Herbal hepatotoxicity: An expanding but poorly defined problem. J Gastroen Hepatol, 2000; 15(10): 1093-1099.

114. Charalampopoulos A, Karatsourakis T, Tsiodra P. Acute hepatitis associated with the use of Mahuang in a young adult. Eur J Intern Med, 2007; 18(1): 81 .

115.Bajaj J, Knox JF, Komorowski R, Saeian K. The irony of herbal hepatitis: Ma-Huang-induced hepatotoxicity associated with compound heterozygosity for hereditary hemochromatosis. Dig Dis Sci, 2003; 48(10): 1925-1928.

116.Gorey JD, Wahlqvist ML, Boyce NW. Adverse reaction to a Chinese herbal remedy. Med J Aust, 1993; 157: 484-486.

117. Wettach GE, Falvey SJ. A mysterious blood pressure increase in a drilling Naval reservist. Mil Med, 2002; 167(6): 521-523.

118. Theoharides T. Sudden death of a healthy college student related to ephedrine toxicity from a ma huang-containing drink. J Clin Psychopharmacol, 1997; 17(5): 437-439.

119.Panis B, Wong DR, Hooymans PM, De Smet PA, Rosias PP. Recurrent toxic hepatitis in a Caucasian girl related to the use of Shou-Wu-Pian, a Chinese herbal preparation. J Pediatr Gastroenterol Nutr, 2005; 41(2): 256-258.

120.Park G, Park GH, Mann SP, Ngu MC. Acute hepatitis induced by Shou-Wu-Pian, a herbal product derived from Polygonum multiflorum. J Gastroenterol Hepatol, 2001; 16(1): 115-117

121. Mazzanti G, Battinelli L, Daniele C, Mastroianni CM, Lichtner M, Costantini S, et al. New case of acute hepatitis following the consumption of Shou Wu Pian, a Chinese herbal product derived from Polygonum multiflorum. Ann Intern Med, 2004; 140(7): W30.

122. Laird AR, Ramchandani N, deGoma EM, Avula B, Khan IA, Gesundheit N. Acute hepatitis associated with the use of an herbal supplement (Polygonum multiflorum) mimicking ironoverload syndrome. J Clin Gastroenterol, 2008; 42: 861-862.

123. But PP, Tomlinson B, Lee KL. Hepatitis related to 
the Chinese medicine Shou-wu-pian manufactured from Polygonum multiflorum. Vet. Hum. Toxicol, 1996; 38: 280-2.

124. Kyoung Ah J, Hyun Ju M, Seung Suk Y, Hong Jun K, Su Nyoung C, Sang Goon S, et al. DrugInduced Liver Injury: Twenty Five Cases of Acute Hepatitis Following Ingestion of Polygonum multifl orum Thunb. Gut And Liver, 2011; 5(4): 493.

125. Furukawa M, Kasajima S, Nakamura Y, Shouzushima M, Nagatani N, Nagahara H, et al. Toxic Hepatitis Induced by Show-Wu-Pian, a Chinese Herbal Preparation. Intern Med, 2010; 49(15): 1537-1540.

126. McRae CA, Agarwal K, Mutimer D, Bassendine MF. Hepatitis associated with Chinese herbs. Eur J Gastroenterol Hepatol, 2002; 14(5): 559.

127. Lei J, Yu J, Yu H, Liao Z. Composition, cytotoxicity and antimicrobial activity of essential oil from Dictamnus dasycarpus. Food Chem, 2008; 107(3): 1205-1209.

128. Levi M, Guchelaar HJ, Woerdenbag HJ, Zhu YP. Acute hepatitis in a patient using a Chinese herbal tea-a case report. Pharm World Sci, 1998; 20(1): 43-44.

129. Perharic-Walton L, Murray, V. Toxicity of Chinese herbal remedies. Lancet, 1992; 340(8820): 674.

130. Kane JA, Kane SP, Jain S. Hepatitis induced by traditional Chinese herbs; possible toxic components. Gut, 1995; 36(1): 146-147.

131. Vautier G, Spiller RC. Safety of complementary medicines should be monitored. BMJ, 1995; 311(7005): 633.

132. Doris B. S, Victor J. N, Leonard B. S. Chapter 26: Hepatotoxicity of Herbal Preparations. Zakim And Boyer's Hepatology, n.d.; 462-475

133. Yamashiki M, Nishimura A, Huang XX, Nobori T, Sakaguchi S, Suzuki H. Effects of the Japanese herbal medicine "Sho-saiko-to" (TJ-9) on interleukin-12 production in patients with $\mathrm{HCV}$ positive liver cirrhosis. Dev Immunol, 1999; 7(1): 17-22.

134.Itoh S, Marutani K, Nishijima T, Matsuo S, Itabashi M. Liver injuries induced by herbal medicine, syo-saiko-to (xiao-chai-hu-tang). Dig Dis Sci, 1995; 40(8): 1845-1848.

135. Srinivasan R, Smolinske S, Greenbaum D. Probable gastrointestinal toxicity of Kombucha tea: is this beverage healthy or harmful?. J Gen Intern Med, 1997; 12(10): 643-644.

136. Schiano TD. Hepatotoxicity and complementary and alternative medicines. Clinics In Liver Disease, 2003; 7(2): 453-473.

137.Perron AD, Patterson JA, Yanofsky NN. Kombucha "mushroom" hepatotoxicity. Ann Emerg Med, 1995; 26(5): 660-661.

138. Centers for Disease Control. Unexplained severe illness possibly associated with consumption of Kombucha tea - Iowa, 1995. MMWR, 1995; 44: 892-900.
139.Kole AD, Jones HD, Christensen R, Gladstein J. A Case of Kombucha Tea Toxicity. J Intensive Care Med, 2009; 24(3): 205-207.

140.Dufresne C and Farnworth E. Tea, Kombucha, and health: a review. Food Res Int, 2000; 33409-421.

141. Vanderperren B, Rizzo M, Angenot L, Haufroid V, Jadoul M, Hantson P. Acute liver failure with renal impairment related to the abuse of senna anthraquinone glycosides. Ann Pharmacother, 2005; 39(7-8): 1353-1357.

142. Soyuncu S, Cete Y, Nokay AE. Portal vein thrombosis related to Cassia angustifolia. Clin Toxicol, 2008; 46(8): 774-777.

143.Beuers U, Spengler U, Pape G. Hepatitis after chronic abuse of senna. Lancet, 1991; 337(8737): 372-373.

144.Leng-Peschlow E. The importance of senna products. Pharmacol, 1992; 44(suppl.1): 1-2.

145.Dietz B, Bolton J. Botanical dietary supplements gone bad. Chem Res Toxicol, 2007; 20(4): 586590.

146.Mack R. "Boldly they rode ... into the mouth of hell". Pennyroyal oil toxicity. N C Med J, 1997; 58(6): 456-457.

147.Gunby P. Plant known for centuries still causes problems today. JAMA, 1979; 241(21):22462247.

148.Furbee RB, Barlotta KS, Allen MK, Holstege CP. Hepatotoxicity associated with herbal products. Clin. Lab. Med 2006; 26: 227-241.

149. Anderson IB, Mullen WH, Meeker JE, Khojasteh Bakht SC, Oishi S, Nelson SD, Blanc PD. Pennyroyal toxicity: measurement of toxic metabolite levels in two cases and review of the literature. Ann Intern Med, 1996; 124(8): 726734.

150.Bakerink JA, Gospe SM Jr. Dimand RJ, Eldridge MW. Multiple organ failure after ingestion of pennyroyal oil from herbal tea in two infants. Pediatrics, 1996; 98(5): 944-947.

151.Lai S, Lim K, Cheng H. Margosa oil poisoning as a cause of toxic encephalopathy. Singapore Med J, 1990; 31(5): 463-465.

152. Sinniah D, Baskaran G. Margosa oil poisoning as a cause of Reye's syndrome. Lancet, 1981; 1(8218): 487-489.

153.Sinniah D, Baskaran G, Vijayalakshmi B, Sundaravelli N. Margosa oil poisoning in India and Malaysia. Trans R Soc Trop Med Hyg, 1981; 75(6): 903-904.

154.Dhongade R, Kavade S, Damle R. Neem oil poisoning. Indian Pediatr, 2008; 45(1): 56-57.

155.Brett J, Beresford R, Sevastos J, Day R. Margosa oil and Neem Extract Poisoning as a Cause of Renal Tubular Acidosis. J Clinic Toxicol, 2011; 1(3).

156.Borrelli F, Izzo AA. Herb-drug interactions with St John's wort (Hypericum perforatum): an update on clinical observations. The AAPS journal, 2009; 11(4): 710-727. 
157. Singh YN. Potential for interaction of kava and St. John's wort with drugs. J Ethnopharmacol, 2005; 100(1-2): 108-113.

158.Ernst E. The risk-benefit profile of commonly used herbal therapies: Ginkgo, St. John's Wort, Ginseng, Echinacea, Saw Palmetto, and Kava. Ann Intern Med, 2002; 136(1): 42-53.

159. Rahimi R, Abdollahi M. An update on the ability of St. John's wort to affect the metabolism of other drugs. Expert Opin Drug Metab Toxicol, 2012; 8(6): 691-708.

160.Bunchorntavakul C, Reddy KR. Review article: herbal and dietary supplement hepatotoxicity. Aliment Pharmacol Ther, 2013; 37(1): 3-17.

161.Gordon RY, Becker DJ, Rader D J. Reduced efficacy of rosuvastatin by St. John's Wort. Am J Med, 2009; 122(2): e1-2.

162.Barone GW, Gurley BJ, Ketel BL, Lightfoot ML, Abul-Ezz SR. Drug interaction between St. John's wort and cyclosporine. Ann Pharmacother, 2000; 34(9): 1013-1016.

163.Karliova M, Treichel U, Malagò M, Frilling A, Gerken G, Broelsch CE. Interaction of Hypericum perforatum (St. John's wort) with cyclosporin A metabolism in a patient after liver transplantation. J Hepatol, 2000; 33(5): 853-855.

164. Van Strater AC, Bogers JP. Interaction of St John's wort (Hypericum perforatum) with clozapine. Int Clin Psychopharmacol, 2012; 27(2): 121-124.

165. Cohen DL, Del Toro Y. A case of valerianassociated hepatotoxicity. J Clin Gastroenterol, 2008; 42(8): 961-962.

166.Patocka J, Jaki J. Biomedically relevant chemical constituents of Valeriana officinalis. J Appl Biomed, 2010; 8(1): 11-18.

167.Hadley S, Petry JJ. Valerian. Am Fam Physician, 2003; 67(8):1 755.

168. MacGregor FB, Abernethy VE, Dahabra S, Cobden I, Hayes PC. Hepatotoxicity of herbal remedies. BMJ, 1989; 299(6708): 1156-1157.

169. Williams CA, Lamprecht ED. Some commonly fed herbs and other functional foods in equine nutrition: a review. Vet J, 2008; 178(1): 21-31.

170.Loeper ME. Mistletoe (Viscum album L.). Long Herb Task Force, 1999; 10: 1-15.

171.Pearl PL, Drillings IM, Conry JA. Herbs in epilepsy: evidence for efficacy, toxicity, and interactions. Semin Pediatr Neurol, 2011; 18(3): 203-208.

172. Harvey J, Colin-Jones DG. Mistletoe hepatitis. Br Med J (Clin Res Ed), 1981; 282(6259): 186-187.

173. Yang L, Aronsohn A, Hart J, Jensen D. Herbal hepatoxicity from Chinese skullcap: A case report. World J Hepatol, 2012; 4(7): 231-233.

174. Islam MN, Downey $\mathrm{F}, \mathrm{Ng} \mathrm{CK}$. Comparative analysis of bioactive phytochemicals from Scutellaria baicalensis, Scutellaria lateriflora, Scutellaria racemosa, Scutellaria tomentosa and Scutellaria wrightii by LC-DAD-MS. Metabolomics, 2011; 7(3): 446-453.
175.Cole IB, Saxena PK, Murch SJ. Medicinal biotechnology in the genus Scutellaria. In Vitro Cell Dev-Pl, 2007; 43(4): 318-327.

176.Hullar TE, Sapers BL, Ridker PM, Jenkins RL, Huth TS, Farraye FA. Herbal toxicity and fatal hepatic failure. Am J Med, 1999; 106(2): 267-268.

177.Miskelly FG, Goodyer LI. Hepatic and pulmonary complications of herbal medicines. Postgrad Med J, 1992; 68(805): 935.

178.Millonig G, Stadlmann S, Vogel W. Herbal hepatotoxicity: acute hepatitis caused by a Noni preparation (Morinda citrifolia). Eur J Gastroenterol Hepatol, 2005; 17(4): 445-447.

179. West B, Su C, Jensen C. Hepatotoxicity and subchronic toxicity tests of Morinda citrifolia (noni) fruit. J Toxicol Sci, 2009; 34(5): 581-585.

180.Stadlbauer V, Fickert P, Lackner C, Schmerlaib J, Krisper P, Stauber RE, et al. Hepatotoxicity of NONI juice: report of two cases. World J Gastroenterol, 2005; 11(30): 4758-4760.

181. Wang MY, West BJ, Jensen CJ, Nowicki D, Su C, Palu AK, Anderson G. Morinda citrifolia (Noni): a literature review and recent advances in Noni research. Acta Pharmacologica Sinica, 2002; 23(12): 1127-1141.

182. Yüce B, Gülberg V, Diebold J, Gerbes AL. Hepatitis induced by Noni juice from Morinda citrifolia: a rare cause of hepatotoxicity or the tip of the iceberg?. Digestion, 2006; 73(2-3): 167170.

183.Elizabeth LY, Sivagnanam M, Ellis L, Huang JS. Acute hepatotoxicity after ingestion of Morinda citrifolia (Noni Berry) juice in a 14-year-old boy. $\mathrm{J}$ Pediatr Gastroenterol Nutr, 2011; 52(2): 222-224.

184.Santi L, Maggioli C, Mastroroberto M, Tufoni M, Napoli L, Caraceni P. Acute liver failure caused by amanita phalloides poisoning. Int J Hepatol, 2012; (2012): 487-480.

185.Cress CM, Malliah A, Herrine SK. Fulminant Hepatic Failure Caused by Amanita phalloides Toxicity. Clin Gastroenterol Hepatol, 2011; 9(2), A26-A26.

186. Yildiz BD, Abbasoglu O, Saglam A, Sökmensüer C. Urgent liver transplantation for Amanita phalloides poisoning. Pediatr Transplant, 2008; 12(1), 105-108.

187. Özçay F, Baskin E, Özdemir N, Karakayali H, Emiroglu R, Haberal M. Fulminant liver failure secondary to mushroom poisoning in children: importance of early referral to a liver transplantation unit. Pediatr Transplant, 2006; 10(2): 259-265.

188. Ward J, Kapadia K, Brush E, Salhanick SD. Amatoxin Poisoning: Case Reports and Review of Current Therapies. J Emerg Med, 2012; 44(1): 116-121.

189.Poppenga RH. Herbal medicine: potential for intoxication and interactions with conventional drugs. Clin Tech Small Anim Pract, 2002; 17(1): 6-18.

190.Craig JO. Poisoning by the volatile oils in childhood. Arch Dis Child, 1953; 28(142): 475. 
191.Elder NC, Gillcrist A, Minz R. Use of alternative health care by family practice patients. Arch Fam Med, 1997; 6(2): 181.

192.Buchanan RL. Toxicity of spices containing methylenedioxybenzene derivatives: A review. J Food Saf, 1978; 1(4): 275-293.

193.Miller LG Herbal medicinals: selected clinical considerations focusing on known or potential drug-herb interactions. Arch Intern Med, 1998; 158(20): 2200.

194.Goldhaber-Fiebert S, Kemper KJ. Echinacea (E. angustifolia, E. pallida, and E. Purpurea). The Longwood Herbal Task Force and The Center for Holistic Pediatric Education and Research, 1999.

195.O'Hara M, Kiefer D, Farrell K, Kemper K. A review of 12 commonly used medicinal herbs. Arch Fam Med, 1998; 7(6): 523-536.

196. Abebe W. Herbal medication: potential for adverse interactions with analgesic drugs. J Clin Pharm Ther, 2002; 27(6): 391-401.

197. Kocaman O, Hulagu S, Senturk O. Echinaceainduced severe acute hepatitis with features of cholestatic autoimmune hepatitis. Eur J Intern Med, 2008; 19(2): 148-148.

198.Licata A, Macaluso FS, Craxì A. Herbal hepatotoxicity: a hidden epidemic. Intern Emerg Med, 2013; 8(1): 13-22.

199. Roulet M, Laurini R, Rivier L, Calame A. Hepatic veno-occlusive disease in newborn infant of a woman drinking herbal tea. J Pediatr, 1988; 112(3): 433-436.

200. Wiedenfeld H, Edgar, J. Toxicity of pyrrolizidine alkaloids to humans and ruminants. Phytochem Rev, 2011; 10(1): 137-151.

201. Stegelmeier BL, Edgar JA, Colegate SM, Gardner DL, Schoch TK, Coulombe Jr RA et al. Pyrrolizidine alkaloids plants, metabolism and toxicity. Nat Toxins, 1999; 8(1): 95-116.

202.Selzer G, Parker RGF. Senecio Poisoning Exhibiting as Chiari's Syndrome: A Report on Twelve Cases*. Am J Pathol, 1951; 27(5): 885 907.

203.Bras G, Jelliffe DB, Stuart KL. Veno-occlusive disease of liver with nonportal type of cirrhosis, occuring in Jamaica. Arch Pathol Lab Med, 1954; 57(4): 285-300.

204.Nelson HD. Seminar: Menopause. Lancet, 2008; 371: 760-770.

205.Borrelli F, Ernst E. Black cohosh (Cimicifuga racemosa): a systematic review of adverse events. Am J Obstet Gynecol, 2008; 199(5): 455-466.

206. Cavaliere C, Rea P, Blumenthal M. Herbal supplement sales in United States show growth in all channels. HerbalGram, 2008; 78: 60-63

207. Tindle HA, Davis RB, Phillips RS, Eisenberg DM. Trends in use of complementary and alternative medicine by US adults: 1997-2002. Altern Ther Health Med, 2005; 11: 42-51.

208.Jacobson JS, Troxel AB, Evans J, Klaus L, Vahdat L, Grann VR, et al. Randomized trial of black cohosh for the treatment of hot flashes among women with a history of breast cancer. J Clin
Oncol, 2001; 19(10): 2739-2745.

209.Lehmann-Wilenbrock E, Riedel HH. Clinical and endocrinologic examinations concerning therapy of climacteric symptoms following hysterectomy with remaining ovaries. Zentralbl Gynakol, 1988; 110: 611-618.

210. Warnecke G. Using phyto-treatment to influence menopausal symptoms. Med Welt, 1985; 36: 87.

211. Stoll W. Phytotherapy influences atrophic vaginal epithelium. Therapeuticon, 1987; 1: 23.

212.Bonne JT. Herbs commonly used by women: An evidence-based review. Am J Obstet Gynecol, 2003; 188(Supplement): S44-S55.

213.Lontos S, Jones RM, Angus PW, Gow PJ. Acute liver failure associated with the use of herbal preparations containing black cohosh. Med J Austral, 2003; 179(7): 390-391.

214.Smith BC, Desmond PV. Acute hepatitis induced by ingestion of the herbal medication chaparral. Aust NZJ Med, 1993; 23(5): 526.

215.Alderman S, Kailas S, Goldfarb S, Singaram C, Malone DG. Cholestatic hepatitis after ingestion of chaparral leaf: confirmation by endoscopic retrograde cholangiopancreatography and liverbiopsy. J Clin Gastroenterol, 1994; 19(3): 242247.

216. Batchelor WJ, Heathcote J, Wanless IR. Chaparral-induced hepatic injury. Am J Gastroenterol, 1995; 90(5): 831-833.

217.Gordon DW, Rosenthal G, Hart J, Sirota R, Baker AL. Chaparral ingestion. The broadening spectrum of liver injury caused by herbal medications. JAMA, 1995; 273(6): 489-490.

218.Estes JD, Stolpman D, Olyaei A, Corless CL, Ham JM, Orloff SL, et al. High prevalence of potentially hepatotoxic herbal supplement use in patients with fulminant hepatic failure. Arch Surg, 2003; 138(8): 852-856.

219. Obermeyer WR, Musser SM, Betz JM, Casey RE, Pohland AE, Page SW. Chemical studies of phyloestrogens in flax and chaparral (43824). Proc Exp Biol Med, 1995; 208: 6-12.

220.Evan AP. Gardner Jr. K. Nephron obstruction in nordihydroguaiaretic acid-induced renal cystic disease. Kidney Int, 1979; 15(1): 7-19.

221. Salari HI, Braquet P, Borgeat P. Comparative effects of indomethacin, acetylenic acids, 15HETE, nordihydroguaiaretic acid and BW755C on the metabolism of arachidonic acid in human leukocytes and platelets. Prostaglandins Leukot Med, 1984; 13(1): 53-60.

222. Wilt TJ, Ishani A, Stark G, MacDonald R, Lau J, Mulrow C. Saw palmetto extracts for treatment of benign prostatic hyperplasia - A systematic review. JAMA, 1998; 280(18): 1604-1609.

223. Lowe FC, Ku JC. Phytotherapy in treatment of benign prostatic hyperplasia: a critical review. Urology, 1996; 48(1): 12-20.

224. Wargo K, Allman E, Ibrahim F. A possible case of saw palmetto-induced pancreatitis. South Med J, 2010; 103(7): 683-685.

225.Frederick C. W, GeorgeW. R. Senecio disease, or 
cirrhosis of the liver due to senecio poisoning. Lancet, 1920; 196(Originally published as Volume 2, Issue 5069): 848-849.

226. No comfort in comfrey. Science Teacher, 2000; 67(5): 14

227. Mattei A, Rucay P, Samuel D, Feray C, Reyenes $\mathrm{M}$, Bismuth $\mathrm{H}$. Liver transplantation for severe acute liver failure after herbal medicine (Teucriumpolium) administration. J Hepatol, 1995; 22(5): 597.

228. Polymeros D, Kamberoglou D, Tzias V. Acute cholestatic hepatitis caused by Teucrium polium (golden germander) with transient appearance of antimitochondrial antibody. J Clin Gastroenterol, 2002; 34:100-101.

229. Vasileiadou E, Karanicolas E, Chrysagis D, Kolokotroni D, Papamihalis E, Banti A, et al. Teucrium polium L. (golden germander)-induced hepatitis: report of 5 cases [Meeting abstract]. J Hepatol, 2003; 38:195.

230.Dourakis SP, Papanikolaou IS, Tzemanakis EN, Hadziyannis SJ. Acute hepatitis associated with herb (Teucrium capitatum L.) administration. Eur J Gastroenterol Hepatol, 2002; 14(6): 693-695.

231.De Vincenzi M, Maialetti F, Silano M. Constituents of aromatic plants: teucrin A. Fitoterapia, 2003; 74(7-8): 746-749.

232.De Berardinis V, Moulis C, Maurice M, Beaune P, Pessayre D, Loeper J, et al. Human microsomal epoxide hydrolase is the target of germanderinduced autoantibodies on the surface of human hepatocytes. Mol Pharmacol, 2000; 58(3): 542-551.

233.Teschke R. Kava hepatotoxicity: pathogenetic aspects and prospective considerations. Liver International, 2010; 30(9): 1270-1279.

234. Stevinson C, Huntley A, Ernst E. A Systematic Review of the Safety of Kava Extract in the Treatment of Anxiety. Drug Saf, 2002; 25(4): 251261.

235. Olsen LR, Grillo MP, Skonberg C. Constituents in kava extracts potentially involved in hepatotoxicity: a review. Chem Res Toxicol, 2011; 24(7): 992-1002.

236. Assessment of the risk of hepatotoxicity with kava products / WorldHealth Organization. Geneva, Switzerland: World Health Organization, c2007.; 2007.

237. Gomes MFPL, Massoco CD, Xavier JG, Bonamin LV. Comfrey (Symphytum Officinale. 1.) and Experimental Hepatic Carcinogenesis: A Shortterm Carcinogenesis Model Study. Evid Based Complement Alternat Med, 2010; 7(2): 197-202.

238. Capdevila J, Gil L, Orellana M. Inhibitors of cytochrome P-450-dependent arachidonic acid metabolism. Arch Biochem Biophys, 1988; 261: 257-263.

239.Wu D, Yu L, Nair MG, De Witt DL, Ramsewak RS. Cyclooxygenase enzyme inhibitory compounds with antioxidant activities from Piper methysticum (kava kava) roots. Phytomedicine, 2002; 9(1), 41-47.
240.Hamouda C, Hedhili A, Ben SN, Zhioua M, Amamou M. A review of acute poisoning from Atractylis gummifera L. Vet Hum Toxicol, 2004; 46(3): 144.

241. Seedat YK, Nathoo BC. Acute renal failure in blacks and Indians in South Africa-comparison after 10 years. Nephron, 2008; 64(2): 198-201.

242. Wainwright J, Schonland MM, Candy HA. Toxicity of Callilepis laureola. S Afr Med J, 1977; 52(8): 313-315.

243. Verucchi G, Calza L, Attard L, Chiodo F. Acute hepatitis induced by traditional Chinese herbs used in the treatment of psoriasis. J Gastroenterol Hepatol, 2002; 17(12): 1342-1343.

244.Larrey D. Drug-induced liver diseases. J hepatol, 2000; 32: 77-88.

245. Thomassen D, Slattery JT, Nelson SD. Menthofuran-dependent and independent aspects of pulegone hepatotoxicity: roles of glutathione. J Pharmacol Exp Ther, 1990; 253(2): 567-572.

246. Thomassen D, Knebel N, Slattery, McClanahan RH, Nelson SD. Reactive intermediates in the oxidation of menthofuran by cytochromes P-450. Chem Res Toxicol, 1992; 5:123-130.

247. Thomassen D, Slattery JT, Nelson SD. Contribution of menthofuran to the hepatotoxicity of pulegone: assessment based on matched area under the curve and on matched time course. J Pharmacol Exp Ther, 1988; 244(3), 825-829

248.Ernst E. Risks of herbal medicinal products. Pharmacoepidemiol Drug Saf, 2004; 13(11): $767-$ 771.

249.Holstege CP, Mitchell K, Barlotta K, Furbee RB. Toxicity and drug interactions associated with herbal products: ephedra and St. John's Wort. Med Clin North Am, 2005; 89(6): 1225.

250.Bos R, Hendriks H, Scheffer JJC, Woerdenbag H J. Cytotoxic potential of valerian constituents and valerian tinctures. Phytomedicine, 1998; 5(3): 219-225.

251.Chan TY, Tang CH, Critchley JA. Poisoning due to an over-the-counter hypnotic, Sleep-Qik (hyoscine, cyproheptadine, valerian). Postgrad Med J, 1995; 71(834): 227-228.

252.Houghton PJ. The biological activity of valerian and related plants. J Ethnopharmacol, 1988; 22(2): 121-142.

253. Mueller BA, Scott MK, Sowinski KM, Prag KA. Noni juice (Morinda citrifolia): Hidden potential for hyperkalemia?. Am J Kidney Dis, 2000; 35(2): 310-312.

254.Bironaite D, Ollinger $\mathrm{K}$. The hepatotoxicity of rhein involves impairment of mitochondrial functions. Chem Biol Interact, 1997; 103(1): 3550 . 
J Pharm Pharmaceut Sci (www.cspsCanada.org) 16(3) 376-404, 2013

\begin{tabular}{|c|c|c|c|c|c|c|}
\hline Herbal remedy & Part used & Toxic constituent & Application & Nature of injury & $\begin{array}{c}\text { Potential Mechanism of } \\
\text { action }\end{array}$ & Reference \\
\hline $\begin{array}{l}\text { Black cohosh } \\
\text { (Actea } \\
\text { racemosa/cimicifuga } \\
\text { racemosa) }\end{array}$ & $\begin{array}{l}\text { Roots } \\
\text { \& Rhizomes }\end{array}$ & $\begin{array}{l}\text { Triterpene } \\
\text { glycoside }\end{array}$ & Menopausal symptoms & $\begin{array}{l}\text { Hepatic necrosis and } \\
\text { bridging fibrosis }\end{array}$ & Autoimmune, Rare & $14,24,25,106$ \\
\hline $\begin{array}{l}\text { Chaparral } \\
\text { (Larrea tridentata) }\end{array}$ & Leaves & $\begin{array}{c}\text { Larrea tridentata } \\
\text { (nordihydroguaiar } \\
\text { etic acid) }\end{array}$ & $\begin{array}{l}\text { Antioxidant } \\
\text { Health tonic }\end{array}$ & $\begin{array}{c}\text { Cholestasis, } \\
\text { Chronic hepatitis, } \\
\text { cholangitis, cirrhosis }\end{array}$ & $\begin{array}{c}\text { Induction of cytochrome } \\
\text { P450 3A } \\
\text { Glutathione depletion }\end{array}$ & 15 \\
\hline $\begin{array}{l}\text { Prostata } \\
\text { (Serenoa repens) }\end{array}$ & Berries & Saw palmetto & $\begin{array}{c}\text { Treatment of benign } \\
\text { prostatic hyperplasia } \\
(\mathrm{BPH})\end{array}$ & Cholestatic hepatitis & $\begin{array}{l}\text { Antiandrogenic and } \\
\text { estrogenic }\end{array}$ & 35,39 \\
\hline Comfrey (syrnphytium) & $\begin{array}{l}\text { Leaves } \\
\& \\
\text { Roots }\end{array}$ & $\begin{array}{l}\text { Pyrrolizidine } \\
\text { alkaloids (PA) }\end{array}$ & $\begin{array}{l}\text { Broken bone, wound } \\
\text { healing, reduce joint } \\
\text { inflammation }\end{array}$ & Hepatic VOD & Veno-occlusive disease & 43,237 \\
\hline $\begin{array}{l}\text { Teucrium chamaedrys } \\
\text { (Wild germander) } \\
\& \\
\text { Teucrium polium }\end{array}$ & Aerial part & $\begin{array}{l}\text { Neo-clerodane } \\
\text { diterpenoids }\end{array}$ & Weight reduction & $\begin{array}{l}\text { Acute and chronic } \\
\text { hepatitis, fibrosis }\end{array}$ & $\begin{array}{c}\text { Cytochrome P450 3A } \\
\text { induction } \\
\text { Glutathione depletion } \\
\text { Autoimmune }\end{array}$ & 5,61 \\
\hline $\begin{array}{l}\text { Kava } \\
\text { (Piper methysticum) }\end{array}$ & $\begin{array}{l}\text { Roots } \\
\text { \& Rhizomes }\end{array}$ & $\begin{array}{l}\text { Kava lactones } \\
\quad \text { (kavain, } \\
\text { dihydrokavain) }\end{array}$ & $\begin{array}{l}\text { Anxiolytic, sleeping } \\
\text { aid (anxiety disorders) }\end{array}$ & $\begin{array}{c}\text { Acute and chronic } \\
\text { hepatitis, } \\
\text { Cholestasis, fulminant } \\
\text { hepatic failure }\end{array}$ & $\begin{array}{c}\text { Idiosyncratic factor } \\
\text { Immunoallergic factor } \\
\text { Poor cytochrome P450 } \\
\text { 2D6 } \\
\text { Cyclooxygenase enzymes } \\
\text { inhibition } \\
\text { (COX-1 and COX-2) } \\
\text { Glutathione depletion }\end{array}$ & 69 \\
\hline $\begin{array}{l}\text { Greater celandine } \\
\text { (Chelidonium majus) }\end{array}$ & Aerial parts & Unknown & $\begin{array}{c}\text { Gastrointestinal tract } \\
\text { disorders }\end{array}$ & $\begin{array}{c}\text { Acute hepatitis } \\
\text { Cholestatic hepatitis } \\
\text { Fibrosis }\end{array}$ & Autoimmune & 106,136 \\
\hline Atractylis gummifera & Roots & $\begin{array}{c}\text { Atractyloside } \\
\& \\
\text { Carboxy- } \\
\text { atractyloside }\end{array}$ & $\begin{array}{c}\text { Antipyretic } \\
\text { Diuretic } \\
\text { Emetic } \\
\text { Purgative } \\
\text { Chewing gum }\end{array}$ & Acute liver failure & Mitochondrial toxicity & $\begin{array}{l}90,91,95 \\
106\end{array}$ \\
\hline
\end{tabular}




\begin{tabular}{|c|c|c|c|c|c|c|}
\hline $\begin{array}{l}\text { Callilepis laureola } \\
\text { (Impila) }\end{array}$ & Roots & atractyloside & Health tonic & $\begin{array}{c}\text { Hepatic necrosis } \\
\text { Renal tubular necrosis }\end{array}$ & $\begin{array}{c}\text { Oxidative phosphorylation } \\
\text { inhibition }\end{array}$ & $101,106,242$ \\
\hline $\begin{array}{l}\text { Jin Bu Huan } \\
\text { (Lycopodium serratum) }\end{array}$ & $\begin{array}{l}\text { Mixture of } \\
\text { herbs }\end{array}$ & $\begin{array}{c}\text { Lypocodium } \\
\text { serratum } \text { extract }\end{array}$ & $\begin{array}{l}\text { Analgesic sedative } \\
\text { Sleeping aid }\end{array}$ & $\begin{array}{c}\text { Acute hepatitis } \\
\text { Chronic hepatitis } \\
\text { Steatosis } \\
\text { Fibrosis } \\
\end{array}$ & Autoimmune & 30,106 \\
\hline $\begin{array}{l}\text { Ma Huang } \\
\text { (Ephedra sinica) }\end{array}$ & Aerial & Alkaloids & Weight loss & Acute hepatitis & Autoimmune & 106,109 \\
\hline $\begin{array}{l}\text { Shou-Wu-Pian } \\
\text { (Polygonum } \\
\text { multiflorum) } \\
\end{array}$ & Root vines & Anthraquinone & $\begin{array}{l}\text { Health tonic } \\
\text { Antiaging } \\
\text { Hair color }\end{array}$ & $\begin{array}{c}\text { Acute hepatitis } \\
\text { Acute liver failure }\end{array}$ & Autoimmune & $106,120,125$ \\
\hline Dictamnus dasycarpus & Root bark & Unknown & $\begin{array}{c}\text { Skin diseases } \\
\text { Cough } \\
\text { Jaundice } \\
\text { Rheumatism }\end{array}$ & $\begin{array}{c}\text { Acute hepatitis } \\
\text { Elevated liver enzymes } \\
\text { Death }\end{array}$ & Unknown & $127,128,129$ \\
\hline Dai-Saiko-to or TJ-8 & $\begin{array}{l}\text { Mixture of } \\
\text { herbs }\end{array}$ & Diterpenoids & $\begin{array}{c}\text { Chronic hepatitis } \\
\text { Dyspepsia } \\
\text { Fever } \\
\text { Gallstones } \\
\end{array}$ & Autoimmune hepatitis & Autoimmune & $10,106,132$ \\
\hline $\begin{array}{l}\text { Syo-saiko-to } \\
\text { Xiao-chai-hu-tang da- } \\
\text { chai-hu-tang } \\
\text { TJ-9 }\end{array}$ & $\begin{array}{l}\text { Mixture of } \\
\text { herbs }\end{array}$ & Glycyrrhizin & Pyretic diseases & $\begin{array}{l}\text { Fatal hepatic necrosis } \\
\text { Hepatic granulomas } \\
\text { Microvesicular steatosis }\end{array}$ & Unknown & 113,134 \\
\hline $\begin{array}{l}\text { Kombucha } \\
\text { "mushroom" Tea }\end{array}$ & Mushroom & Usnic acid & $\begin{array}{c}\text { Wight loss } \\
\text { Increasing T-cell count } \\
\text { Well-being } \\
\text { Antiaging }\end{array}$ & $\begin{array}{c}\text { Acute liver failure } \\
\text { Hepatitis } \\
\text { Acute renal failure with } \\
\text { hyperthermia and lactic } \\
\text { acidosis }\end{array}$ & $\begin{array}{c}\text { Cytochrome } \\
\text { polymorphism } \\
\text { Oxidative stress } \\
\text { Mitochondrial toxicity }\end{array}$ & $106,137,139$ \\
\hline $\begin{array}{l}\text { Cassia angustifolia } \\
\text { (senna) }\end{array}$ & $\begin{array}{l}\text { Leaves } \\
\text { (pods) and } \\
\text { fruits } \\
\end{array}$ & $\begin{array}{l}\text { Anthraquinone } \\
\text { Sennosides }\end{array}$ & $\begin{array}{c}\text { Laxative } \\
\text { Constipation }\end{array}$ & $\begin{array}{c}\text { Acute hepatitis } \\
\text { Acute cholestatic hepatitis } \\
\text { Acute liver failure }\end{array}$ & Unknown & $106,141,142$ \\
\hline $\begin{array}{l}\text { Pennyroyal oil } \\
\text { (Hedeoma pulegoides \& } \\
\text { Mentha pulegium) }\end{array}$ & Leaves & Pulegone & $\begin{array}{c}\text { Abortifacient } \\
\text { Upper respiratory tract } \\
\text { Ear infection }\end{array}$ & $\begin{array}{l}\text { Fulminant liver failure } \\
\text { Hepatic dysfunction with } \\
\text { epileptic Encephalopathy }\end{array}$ & $\begin{array}{c}\text { Glutathione depletion } \\
\text { Cytochrome P450 } \\
\text { induction }\end{array}$ & 106,150 \\
\hline $\begin{array}{l}\text { Margosa oil } \\
\text { (Azadirachta indica }\end{array}$ & Seeds & $\begin{array}{c}\text { Bitters } \\
\text { constituents }\end{array}$ & Health tonic & Reye's syndrome & Unknown & $100,106,152$ \\
\hline
\end{tabular}


J Pharm Pharmaceut Sci (www.cspsCanada.org) 16(3) 376-404, 2013

\begin{tabular}{|c|c|c|c|c|c|c|}
\hline $\begin{array}{l}\text { St. John's Wort } \\
\text { (Hypericum perforatum) }\end{array}$ & Aerial & Hyperforin & Anti-depressant & $\begin{array}{c}\text { Reduce blood cyclosporine } \\
\text { levels } \\
\text { Reduce plasma anticancer } \\
\& \text { antiretroviral drug levels } \\
\text { Serotonin syndrome } \\
\text { unwanted pregnancies } \\
\end{array}$ & $\begin{array}{c}\text { Cytochrome P450 } \\
\text { induction } \\
\text { P-glycoprotein induction }\end{array}$ & $\begin{array}{c}156,158,159 \\
249\end{array}$ \\
\hline $\begin{array}{l}\text { Valerian } \\
\text { (Valeriana officinalis) }\end{array}$ & Root & Valepotriates & $\begin{array}{c}\text { Sedative } \\
\text { Anti-anxiety }\end{array}$ & Hepatitis & Unknown & $\begin{array}{c}106,152,165,1 \\
68 \\
\end{array}$ \\
\hline $\begin{array}{l}\text { Mistletoe } \\
\text { (Viscum album) }\end{array}$ & All parts & Diterpenoids & $\begin{array}{c}\text { Hypertension Insomnia } \\
\text { Epilepsy } \\
\text { Asthma } \\
\text { Infertility } \\
\text { Urinary disorders } \\
\end{array}$ & Acute hepatitis & Unknown & 30,171 \\
\hline $\begin{array}{l}\text { Skullcap } \\
\text { (Scutellaria baicalensis) }\end{array}$ & - & Terpenoid & $\begin{array}{c}\text { Sedative } \\
\text { Anti-inflammatory }\end{array}$ & $\begin{array}{c}\text { Veno-ooclusive disease } \\
\text { Subsequent fatal liver } \\
\text { failure } \\
\text { Cholestatsis } \\
\text { Hepatitis } \\
\end{array}$ & Veno-occlusive disease & $106,173,176$ \\
\hline $\begin{array}{l}\text { Noni juice } \\
\text { (Morinda citrifolia) }\end{array}$ & $\begin{array}{c}\text { Fruit Roots } \\
\qquad \begin{array}{c}\& \\
\text { Leaves }\end{array}\end{array}$ & Anthraquinone & Health tonic & $\begin{array}{l}\text { Sub acute hepatic failure } \\
\text { Acute hepatitis }\end{array}$ & $\begin{array}{c}\text { Glutathione depletion } \\
\text { Mitochondrial membrane } \\
\text { potential reduction } \\
\text { Lipid peroxidation } \\
\text { initiation } \\
\end{array}$ & $\begin{array}{c}106,178,180,2 \\
54\end{array}$ \\
\hline Amanita phalloides & Mushroom & $\begin{array}{c}\text { Phalloidin \& } \\
\alpha \text { - amanitin } \\
\end{array}$ & Food & $\begin{array}{c}\text { Fulminant liver failure } \\
\text { Death }\end{array}$ & $\begin{array}{c}\text { Inhibition of RNA } \\
\text { polymerase II }\end{array}$ & $184,185,187$ \\
\hline $\begin{array}{l}\text { Sassafras } \\
\text { (Sassafras albidum) }\end{array}$ & $\begin{array}{c}\text { Root } \\
\& \\
\text { Root bark }\end{array}$ & Safrole & $\begin{array}{c}\text { Sudorific agent } \\
\text { Inflammation of eyes } \\
\text { Urinary tract \& kidney } \\
\text { diseases }\end{array}$ & Rare in human & Unknown & 189 \\
\hline $\begin{array}{l}\text { Echinacea } \\
\text { E. angustifolia } \\
\text { E. pallida } \\
\text { E. purpurea }\end{array}$ & All parts & $\begin{array}{c}\text { Pyrrolizidine } \\
\text { alkaloids } \\
\text { (lack } 1,2 \text { saturated } \\
\text { necrine ring) }\end{array}$ & $\begin{array}{l}\text { Respiratory infection } \\
\text { Fever } \\
\text { Immune booster }\end{array}$ & $\begin{array}{l}\text { Acute cholestatic } \\
\text { autoimmune hepatitis }\end{array}$ & Unknown & $194,195,197$ \\
\hline
\end{tabular}

